\title{
Fish size selection and diet composition of Eurasian otters (Lutra lutra) in salmonid streams: Picky gourmets rather than opportunists?
}

\author{
Marcia Sittenthaler ${ }^{1,2, *}$, Lucia Koskoff ${ }^{3}$, Kurt Pinter $^{3}$, Ursula Nopp-Mayr ${ }^{1}$, Rosemarie Parz-Gollner ${ }^{1}$ \\ and Klaus Hackländer ${ }^{1}$ \\ ${ }^{1}$ Institute of Wildlife Biology and Game Management, Department of Integrative Biology and Biodiversity Research, University of \\ Natural Resources and Life Sciences, Vienna, Gregor-Mendel Str. 33, 1180 Vienna, Austria \\ ${ }^{2}$ Central Research Laboratories, Natural History Museum Vienna, Burgring 7, 1010 Vienna, Austria \\ ${ }^{3}$ Institute of Hydrobiology and Aquatic Ecosystem Management, Department of Water - Atmosphere - Environment, University of \\ Natural Resources and Life Sciences, Vienna, Gregor-Mendel Str. 33, 1180 Vienna, Austria
}

Received: 18 November 2018 / Accepted: 30 April 2019

\begin{abstract}
Knowledge on predator diet and drivers of prey selection is particularly of interest for an efficient management of predator and prey populations where predators potentially compete with humans for resources. Actual or perceived predation by Eurasian otter (Lutra lutra) on fish stocks generates conflicts in many countries. Recently, conflicts are heating up in riverine habitats, where multiple stressors affect stream fish populations. We combined dietary analysis of otter faeces and prey fish availability in three Austrian streams to assess spatial and seasonal differences in diet composition, the extent of (salmonid) fish consumption and the selection for specific salmonid fish sizes relative to their availability. Otters in upper reaches of temperate salmonid streams occupied a narrow trophic niche. Overall, otters fed predominantly on fish with salmonids dominating diet, both in terms of frequency and ingested biomass measures. Within the category of salmonids, otters selected for specific size classes. Concurrently, otters also displayed an opportunistic feeding behaviour, and seasonally and locally non-fish prey and other fish species than salmonids became key resources. Diet composition and salmonid size selection varied significantly within and between streams, which we relate to spatio-temporal variations of prey community composition and stream-specific habitat characteristics affecting prey vulnerability.
\end{abstract}

Keywords: otter faeces / salmonid fish / feeding ecology / predator diet / human-wildlife conflict

Résumé - Choix de la taille des poissons et composition du régime alimentaire des loutres d'Europe (Lutra lutra) dans des cours d'eau à salmonidés: des gourmets difficiles plutôt que des opportunistes? Les connaissances sur le régime alimentaire des prédateurs et les facteurs de sélection des proies sont particulièrement intéressantes pour une gestion efficace des populations de prédateurs et de proies où les prédateurs sont potentiellement en compétition avec les humains pour les ressources. La prédation réelle ou perçue de la loutre d'Europe (Lutra lutra) sur les stocks de poissons génère des conflits dans de nombreux pays. Récemment, les conflits se sont intensifiés dans les habitats de rivière, où de multiples facteurs de stress affectent les populations de poissons des cours d'eau. Nous avons combiné l'analyse alimentaire des fèces de loutres et de la disponibilité des poissons proies dans trois cours d'eau autrichiens pour évaluer les différences spatiales et saisonnières dans la composition du régime alimentaire, l'importance de la consommation de poissons (salmonidés) et la sélection en fonction des tailles spécifiques de poissons salmonidés par rapport à leur disponibilité. Les loutres dans le cours supérieur des cours d'eau de salmonidés tempérés occupaient une niche trophique étroite. Dans l'ensemble, les loutres se nourrissaient principalement de poissons et les salmonidés dominaient leur régime alimentaire, tant en termes de

\footnotetext{
*Corresponding author: marcia.sittenthaler@boku.ac.at,

marcia.sittenthaler@nhm-wien.ac.at
} 
fréquence que de biomasse ingérée. Dans la catégorie des salmonidés, les loutres sélectionnées pour des classes de taille spécifiques. Simultanément, les loutres ont également affiché un comportement alimentaire opportuniste et, sur le plan saisonnier et local, des proies autres que des poissons et d'autres espèces de poissons que les salmonidés sont devenues des ressources clés. La composition de l'alimentation et le choix de la taille des salmonidés variaient considérablement à l'intérieur des cours d'eau et d'un cours d'eau à l'autre, ce qui est lié aux variations spatio-temporelles de la composition des communautés de proies et des caractéristiques de l'habitat des cours d'eau qui affectent leur vulnérabilité.

Mots clés : fèces de loutres / poissons salmonidés / écologie alimentaire / régime alimentaire des prédateurs / conflit entre l'homme et la faune

\section{Introduction}

Knowledge on predator diet composition and prey selection enables us to evaluate predator-prey relationships and to understand inter- and intraspecific factors affecting wildlife populations. A fundamental question in foraging ecology is whether a specific prey type is consumed because it is more abundant, easier to catch, or because the predator has a specific preference for it. According to the optimal foraging theory (MacArthur and Pianka, 1966; Pyke et al., 1977), individuals exhibit a feeding strategy that maximizes the net rate of energy intake, weighing the energy benefits and costs of prey types. For predators, the consumption of a prey type is associated with a certain searching and handling time as well as attack success rate. Hence, foraging decisions are influenced by intrinsic factors including health, size, sex, social and reproductive status and experience of the forager (e.g. Heggberget and Moseid, 1994; Estes et al., 2003; Araújo et al., 2011; Michalik et al., 2013). Secondly, extrinsic factors like prey community composition, prey and predator densities, interactions within the predator guild, activity patterns and spatial distribution of prey types are main drivers influencing predation and diet choices (e.g. Vucetich et al., 2002; Svanbäck and Bolnick, 2005; Rosenblatt et al., 2015). These factors may also vary seasonally and can be related to habitat characteristics (e.g. Day et al., 2015; Czernik et al., 2016). In case of an opportunistic foraging strategy, diet composition simply reflects present prey availability. Fluctuations in prey availability and accessibility are consequently reflected in the diet composition of an opportunistic consumer throughout time and space. Diet specialists on the other side may spend relatively more time and energy to find the most profitable prey (Stephens and Krebs, 1986).

Information on feeding ecology is particularly of interest for an efficient and effective management of predator populations that have long suffered from persecution and habitat deterioration and by now are recovering due to increased conservation attention (Chapron et al., 2014; Ripple et al., 2014). After decades of predator absence, in many areas, the expansion of these populations carries the potential for inducing humanwildlife conflicts, especially where predators compete with humans for specific resources, as it is the case with the fish-eating Eurasian otter (Lutra lutra) (Klenke et al., 2013).

The recovery of the Eurasian otter in many parts of Europe (Roos et al., 2015) has coincided with conflicts between stakeholder groups, namely commercial fisheries, recreational anglers, and nature conservation proponents. Otter presence and its feeding requirements have been associated with substantial losses of pond fish or a decrease of stream fish populations, respectively (Kranz, 2000; Klenke et al., 2013). Recently, this conflict is getting even more severe in riverine habitats especially in the upper regions of salmonid streams, which are crucial refuges and habitats for brown trout (Salmo trutta) (Pletterbauer et al., 2015). These habitats and trout themselves are valued by recreational anglers (Grant and Harrington, 2015; Sittenthaler et al., 2015; Lyach and Cech, 2017). Nevertheless, otter predation on fish relevant for recreational angling and the influence of otters on fisheries yield in running waters are poorly investigated.

After a long time of predator absence in aquatic ecosystems, prey species are exposed again to natural predation, and as apex predators, otters might have the potential to alter prey community composition and densities. Moreover, nearly all European river basins are affected by human activities, which have modified hydrology, morphology, connectivity and chemical conditions of running waters and have severe impacts on aquatic habitats and aquatic organisms (Schinegger et al., 2012, Schinegger et al., 2016). Altogether, these circumstances might have consequences for fisheries and conservation management and may require new practices and strategies to solve this conflict (Rauschmayer et al., 2008; Redpath et al., 2013; Carter and Linnell, 2016).

In most studies on otter diet, undigested hard prey remains in otter faeces have been used to describe the dietary composition and prey selection of otters (reviewed by Carss, 1995). These studies have shown that otters are top predators which forage upon a large variety of prey species restricted to aquatic and semiaquatic habitats and they highlighted the trophic flexibility of otters (reviewed by Clavero et al., 2003; Krawczyk et al., 2016). Overall, fish are preferred by otters, as shown by captive experiments (Erlinge, 1968) and, consequently, fish are the primary food resource for otters, whenever abundant (Clavero et al., 2003; Krawczyk et al., 2016; Lanszki et al., 2016). Alternative prey species include amphibians, crustaceans, small mammals, reptiles, birds, and insects (Brzezinski et al., 2006; Kruuk, 2006; De La Hey, 2008; Pagacz and Witczuk, 2010; Almeida et al., 2013). Along the continuum from specialists to generalists, otters can be understood as specialists, because of their morphological and physiological adaptions to the aquatic environment and prey (Estes, 1989; Kruuk, 2006). Within this specialism, otters are supposed to feed opportunistically according to the availability of prey resources (Mason and MacDonald, 1986). Due to changes in availability and vulnerability of the prey communities throughout the year, otters can vary their diet to take advantage of seasonal changes in availability, and they show a certain degree of plasticity in their foraging behaviour 
(Remonti et al., 2008; Reid et al., 2013; Krawczyk et al., 2016). Otter prey diversity and trophic niche breadth also depend on ecosystem stability (Ruiz-Olmo and Jiménez, 2009), habitat type and habitat characteristics (e.g. Clavero et al., 2004; Lanszki et al., 2016) and they vary also with latitude and climatic conditions (Clavero et al., 2003; Krawczyk et al., 2016). Some other studies showed that otters also used food resources disproportionately to their availability in terms of prey fish species and/or fish sizes: for riverine habitats (Taastrom and Jacobsen, 1999; Remonti et al., 2010; Grant and Harrington, 2015), fish farms and pond areas (Kloskowski, 2000; Lanszki et al., 2001), and reservoirs (SalesLuís et al., 2007). However, studying prey selection requires estimates of prey availability in the environment, data which is often lacking or difficult to get. Moreover, dietary habits of otters have been described for many habitat types and regions throughout their distribution range in Eurasia (Clavero et al., 2003; Krawczyk et al., 2016), but little knowledge is available on food habits of otters in salmonid streams in temperate zones, where the prey fish spectrum is naturally narrow with salmonids (Salmonidae) and cottids (Cottidae) as the dominating fish families.

Considering recent developments of human-wildlife conflicts in the upper and lower trout regions of running waters and the current state of knowledge for these areas, here we present the results of a study combining data on prey fish availability as well as dietary analysis of otter faecal samples simultaneously. We address the following aspects:

- the assessment of year-round otter diet composition and trophic niche breadth, focusing on the actual extent of fish consumption by otters and the importance of alternative prey resources;

- the selection for specific salmonid fish sizes relative to salmonid availability in streams;

- spatial and seasonal differences in otter diet composition and preferences, which we discuss in context of habitat characteristics and probable patterns of prey availability and vulnerability.

\section{Material and methods}

\subsection{Study sites}

The study was carried out on three salmonid streams of the upper Danube basin in Austria in the Province of Lower Austria: River Ysper, River Ois and River Piesting (Fig. 1), hereinafter referred to as study area $\mathrm{Y}, \mathrm{O}$ and $\mathrm{P}$. The study sites covered 28.8, 33.9 and 32.2 stream kilometres, respectively, of the upper reaches of the streams including the main tributaries. While stream $\mathrm{O}$ and $\mathrm{P}$ are typical pre-alpine streams of the Limestone Alps, stream Y is characterized by a crystalline substrate. Furthermore, the three streams differ in their natural habitat characteristics, with stream $\mathrm{O}$ being up to three times wider than the other two streams and having a considerably higher mean discharge (Tab. 1) and deep pools up to $4 \mathrm{~m}$ in depth. Typical for headwater regions the natural characteristic of all streams is largely undisturbed (BMLFUW, 2015). Individual anthropogenic interventions exist in the form of bank stabilisations, or groundsills. According to the longitudinal zonation of running waters (Illies, 1961) and the ichthyological classification, all river stretches investigated belong to the epi- and metarhithral. Hence, the fish fauna is dominated by salmonids, including brown trout and rainbow trout (Oncorhynchus mykiss), as well as graylings (Thymallus thymallus) and bullheads (Cottus gobio).

The influence of fisheries management in the respective study sites was marginal. During the study period 2014-2015, stocking of fish was abandoned in stream Y, which was the only stream where artificially reared fish have been released in recent years. No fish were harvested during the study in streams $\mathrm{P}$ and $\mathrm{Y}$. In stream $\mathrm{O}$, the fisheries management regulations followed a very restrictive and ecosystem-based approach allowing only a low number of fish to be harvested (Unfer and Pinter, 2018).

Within the catchment area of stream Y, a notable number of artificial ponds (mainly for angling and fish farming purposes) exists: compared to stream $\mathrm{O}$ and $\mathrm{P}$ with 12 and 16 ponds respectively, 45 ponds are present in the closer proximity of stream Y (within a typical otter home range size). These were stocked mainly with common roach (Rutilus rutilus), carp (Cyprinus carpio), perch (Perca fluviatilis) and predatory fish like pike (Esox lucius) and pikeperch (Sander lucioperca), and in former times also with non-native, invasive signal crayfish (Pacifastacus leniusculus). Movements of pond fish into the streams could be excluded, as these ponds are not connected to the investigated streams.

At the time of our study, otter densities in all three study areas were assumed to be at carrying capacity, with $0.14,0.09$ and 0.12 otter territories per stream kilometre for stream Y, O and $\mathrm{P}$, respectively (Sittenthaler et al., unpublished data).

\subsection{Sampling of otter faeces}

Between April 2014 and July 2015, otter faeces (spraints) were collected bimonthly along the entire length of the three stream sections under study (on sand banks, rocks, tributary outfalls, banks under bridges). DNA analysis of a subsample ( $20 \%$ of all samples) suggested that collectors identified otter spraints correctly $(100 \%)$ by their characteristic odour, contents and appearance (Sittenthaler et al., unpublished data). According to the collection date, samples were assigned to seasons: spring (March-May), summer (June-August), autumn (September-November) and winter (December-February). Whole spraints were collected in individual plastic tubes or bags and stored at $-20^{\circ} \mathrm{C}$ until further analysis.

\subsection{Dietary analysis}

We studied otter diet composition by analysis of hard prey remains in otter spraints (Webb, 1976). In a first step, the scats were soaked in a detergent solution for at least 12 hours to break up prey remains and mucoid material, then washed through a $0.5-\mathrm{mm}$ mesh sieve and dried at room temperature (i.e. on average $21^{\circ} \mathrm{C}$ ). Undigested prey remains (vertebrae, bones, scales, feathers, hair, teeth, exoskeleton segments, insect wings) were sorted and divided into eight major groups: fish, crayfish, amphibians, mammals, birds, reptiles, insects and undefined prey. Hard prey remains which could not be assigned to one of the major prey group were categorised as 'undefined prey'. Whenever possible, fish remains were identified to the lowest taxonomic level from diagnostic bones (e.g. vertebrae, jawbones, operculum) and scales using 


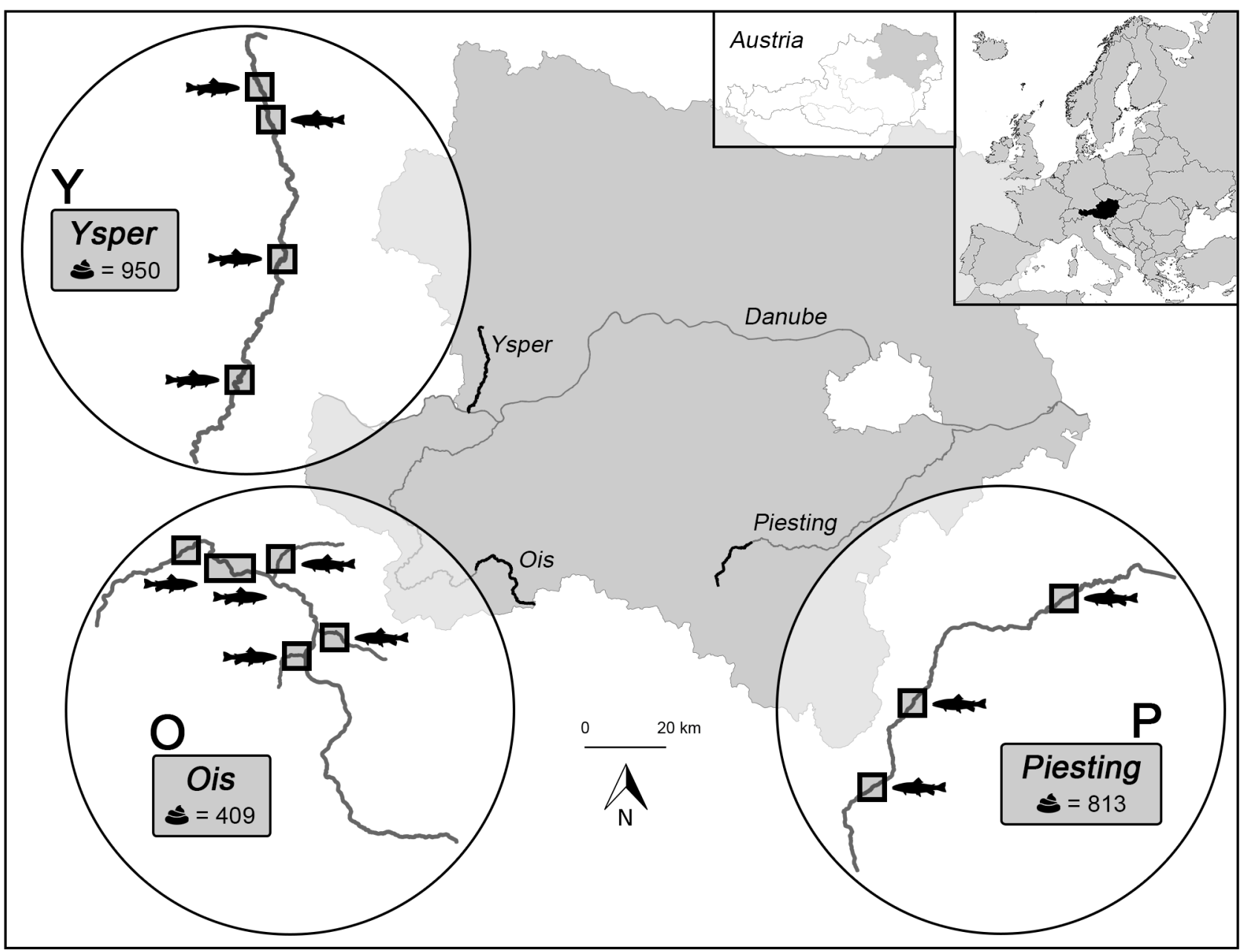

Fig. 1. Location of study sites (Y: Ysper; O: Ois; P: Piesting) in the province of Lower Austria in Austria, Europe (insets). Map extracts in circles show the stream sections where faeces of otters (Lutra lutra) were collected (sample sizes are given); the rectangles represent electrofishing sites. For reasons of clarity, tributaries are not shown for river Ysper and Piesting.

personal reference collections (consisting of all species and size classes expectable in the study areas) and taxonomic keys by Webb (1976), Wise (1980), Knollseisen (1996) and Conroy et al. (2005). Remains of trout species (brown trout and rainbow trout) were pooled and categorised as 'salmonids', as they are not distinguishable. Identified cyprinid fish species were summarised as 'cyprinids'. Fish remains which could only be identified as fish without information on the family level were summarized to 'fish undefined' category.

The minimum number of individuals of each prey category in a spraint was estimated from the number, size and position (leftright) of paired and single diagnostic hard parts (i.e. mouth bones for fish, uropods and antennae for crayfish). In case of missing such diagnostic structures, it was assumed that remains of a certain prey type, e.g. vertebrae of similar size or fragments of a crayfish exoskeleton, belonged to a single individual, following the concept of Wise (1980) to avoid overestimation.

For each study site and season, otter diet composition was expressed in two ways:

- as relative frequency of occurrence (RFO\%): number of occurrences of a prey category divided by the total number of occurrences of all prey categories (Conroy et al., 2005);
- as percentage of ingested biomass (BIO\%): total biomass of a prey category divided by the total biomass of all prey categories.

Regarding feeding ecology, the latter is more relevant, providing the best approximation of the true diet of predators (Klare et al., 2011).

The use of either frequency or biomass based indices for the assessment of otter diet has been discussed elsewhere (Carss and Parkinson, 1996; Jacobsen and Hensen, 1996; Krawczyk et al., 2016). In our study, we used both approaches to facilitate comparison with other studies carried out in this field, and secondly, to overcome specific biases related to different methods. To test for differences between the methods, we used $\chi^{2}$ tests.

To estimate the original sizes (i.e. total lengths) of consumed salmonids and bullheads, we measured vertebrae and atlases found in spraints to the nearest $0.1 \mathrm{~mm}$ with a calliper and applied the regression formulae of Hájková et al. (2003). In a next step, the resulting values were assigned to following size classes: salmonids $\mathrm{A}<120 \mathrm{~mm}$ (representing all young of the year), salmonids B $120-250 \mathrm{~mm}$ 
Table 1. Characteristics of study sites Y (Ysper), O (Ois) and P (Piesting) and number of otter faecal samples analysed per season (Sp: spring; Su: summer; Au: autumn; Wi: winter).

\begin{tabular}{|c|c|c|c|c|c|c|c|c|c|c|c|c|}
\hline \multirow[t]{2}{*}{ Study site } & \multirow{2}{*}{$\begin{array}{l}\text { Length } \\
(\mathrm{km})\end{array}$} & \multirow{2}{*}{$\begin{array}{l}\text { Altitude } \\
\text { (m a.s.1.) }\end{array}$} & \multirow[t]{2}{*}{ Fish region } & \multirow[t]{2}{*}{ Geology } & \multirow{2}{*}{$\begin{array}{l}\text { Mean } \\
\text { width (m) }\end{array}$} & \multirow{2}{*}{$\begin{array}{l}\text { Mean discharge } \\
\text { MQ }\left(\mathrm{m}^{3} / \mathrm{s}\right)\end{array}$} & \multirow[t]{2}{*}{ Ponds } & \multicolumn{5}{|c|}{ Faecal samples analysed } \\
\hline & & & & & & & & $\mathrm{Sp}$ & $\mathrm{Su}$ & $\mathrm{Au}$ & Wi & Total \\
\hline $\mathrm{Y}$ & 28.8 & $220-917$ & Epi- / meta-rhithral & Crystalline & $3-7$ & 0.6 & 45 & 218 & 191 & 154 & 387 & 950 \\
\hline $\mathrm{O}$ & 33.9 & $593-1,021$ & Epi- / meta-rhithral & Limestone & $7-20$ & 4.5 & 12 & 109 & 99 & 141 & 60 & 409 \\
\hline $\mathrm{P}$ & 32.2 & $474-861$ & Epi- / meta-rhithral & Limestone & $4-9$ & 1.0 & 16 & 179 & 187 & 111 & 336 & 813 \\
\hline
\end{tabular}

(representing the mid-range segment of the population), salmonids $\mathrm{C}>250 \mathrm{~mm}$ (representing fish of harvestable sizes for anglers); bullheads $\mathrm{A}<100 \mathrm{~mm}$, bullheads $\mathrm{B}>100 \mathrm{~mm}$. In the case of lack of vertebrae, fish lengths were assessed by comparing size of other diagnostic bones (e.g. jawbones) to the personal reference collection from fish of known size, followed by the assignment to one of the size classes (using the median length of each size class according to each study site).

To estimate the biomass intake of salmonids, bullheads and graylings consumed by otters, we related fish lengths to fish mass by a species-specific and site-specific (crystalline or limestone substrate) exponential regression formula (unpublished data; Tab. S1 in Online Resource 1).

For other fish species, length and weight were assessed by comparison of diagnostic bones found in otter spraints to our personal reference collection consisting of fish of known size. Ingested biomass of other prey categories was estimated using mean weight of specimen caught in the study sites and based on literature: insects $1 \mathrm{~g}$, crayfish $50 \mathrm{~g}$, mammals $30 \mathrm{~g}$, reptiles $50 \mathrm{~g}$, amphibians $30 \mathrm{~g}$, birds $100 \mathrm{~g}$ (Beja, 1996; Clavero et al., 2004; Blanco-Garrido et al., 2008; Smiroldo et al., 2009; Kloskowski et al., 2013).

\subsection{Seasonal and spatial variation in otter diet composition}

To evaluate the multivariate effects of study sites and seasons on otter diet composition, we used Principal response curves (PRC), a multivariate approach based on constrained ordination techniques (Van den Brink and Ter Braak, 1999; Van den Brink et al., 2009). PRC is a derivative of redundancy analysis using seasons as a set of co-variables and the interaction between seasons and stream localities as a set of explanatory variables. Thereby, the time-series of one stream act as a 'reference site' and deviations from this reference are shown for the other sites. As described by Van den Brink et al. (2009), the first principal component of variance being explained by the interaction of site locality and season, is displayed on the y-axis, whereas sampling seasons are depicted on the $\mathrm{x}$-axis. On a second $\mathrm{y}$-axis, socalled species weights $\left(b_{k}\right)$ represent the affinity of single prey categories to the community-based response curve, which allow an interpretation at the prey category level. The sign of the canonical coefficient $\mathrm{C}_{d t}$ indicates the type of community response and must be interpreted by comparison with the signs of species weights $b_{k}$. Prey categories with the same algebraic sign as the overall response curve show a corresponding response, whereas prey categories with an opposite sign than the community response are negatively correlated to the overall response curve. Prey categories with a species weight close to zero either show no response or a response unrelated to the overall pattern displayed by the PRC. Curves need to be interpreted relative to the zero line, i.e. the reference site. As our data already met the assumption of linearity for the PRC (Van den Brink et al., 2003), we did not log-transform them. We tested the significance of the PRC by performing Monte Carlo permutations $(n=999)$. We further ran Monte Carlo permutation tests for each season, looking at the significance of the stream locality per season. For PRC, we used the function 'prc' of the package vegan 2.4-4 (Oksanen et al., 2018) using R 3.4.2 statistic software (R Core Team, 2017), applying a scaling of three.

Furthermore, we used $\chi^{2}$ tests to detect seasonal differences within a study site. Prey categories were pooled to fulfil criteria for $\chi^{2}$ test, i.e. maximal $20 \%$ of all cases showed expected frequencies $<5$ and all expected frequencies were $\geq 1$ : salmonids, bullheads, other fish, crayfish, amphibians, others.

In addition to the spatial and seasonal analyses mentioned above, indices for trophic niche breadth and niche overlap of otter diet were calculated (proportions of undetermined prey remains 'undefined prey', and 'fish undefined' were excluded). Standardised Levins index (Levins, 1968) was used to quantify niche breadth seasonally within each study site as well as among the three study sites. Standardised Levins index is defined as $B A=\left(\left(1 / \Sigma p_{i}{ }^{2}\right)-1\right) /(n-1)$, where $p_{i}$ is the proportion of each prey category and $n$ is the number of possible resources. $B A$ ranges from 0 to 1 , where 0 means only one prey category is consumed and 1 means that all prey categories are consumed in equal proportions.

Pairwise niche overlap between seasons within study sites and among study sites was computed using Pianka's index (Pianka, 1973): $O_{j k}=\Sigma\left(p_{i j} \times p_{i k}\right) / \sqrt{ }\left(\Sigma p_{i j}{ }^{2} \times \Sigma p_{i k}{ }^{2}\right)$, where $O_{j k}$ is the measure for niche overlap between predator $j$ and predator $k, p_{i j}$ is the proportion of prey type $i$ in relation to the total amount of prey ingested by predator $j$, and $p_{i k}$ is the proportion of prey type $i$ in relation to the total amount of prey consumed by predator $k$. $O_{j k}$ ranges from 0 to 1 , where 0 means no overlap between $j$ and $k$ exists, and 1 means a total overlap.

\subsection{Estimating prey fish availability}

We assessed prey fish availability by electrofishing surveys in autumn 2014 for the three study sites (Fig. 1). 
Based on expert judgements and following the national guidelines for fish sampling (Haunschmid et al., 2010), representative sampling stretches were selected according to habitat characteristics of the entire stream under study. The average length of the sampled stretches measured $180 \mathrm{~m}$ (median $164 \mathrm{~m}$ ) and followed the requirements of the European Standard for the sampling of fish with electricity (CEN, 2003). To prevent fish from escaping upstream a block net was installed at the upper end of each stretch. Multiplepass depletion surveys were carried out beginning at the lower end of each stretch. Depending on the river width up to 5 anode handlers waded upstream in a line, to cover the whole cross-section with the electric field (see Pinter et al., 2018 for detailed information on the sampling gear and further sampling procedures). All sampled fish were measured in length (total length in $\mathrm{mm}$ ) and were weighed to the nearest $\mathrm{g}$. According to their lengths, salmonid species and bullheads (as the dominating species) were assigned to the size classes mentioned above (salmonids A, B, C; bullheads A, B).

Based on the real catch data (see Figs. S1-S6 in Online Resource 1) pooled for all fish sampling sites and all sampling passes per study area, we determined fish species and size composition and used the catch per unit effort (CPUE; Cowx, 1991) to quantify prey fish availability. Prey fish data were expressed in two ways: abundance (individuals) and biomass (kg) per $100 \mathrm{~m}$ stream length. As bullheads show a lack of a swim bladder and are bottom-dwelling fish which are hiding between and under stones, electrofishing surveys did not provide precise quantitative information on their availability for otters - in contrast to data on salmonids. Due to these species-specific detection probabilities between bullheads and salmonids, our data only allowed a comparison of bullhead occurrence across streams, but not selectivity analysis between species. However, within the category of salmonids, CPUE calculations provided precise information on population demographics, and hence, relative availability of salmonid size classes.

For prey fish availability in ponds within the catchment area and home range of resident otters, we only had qualitative personal observations and narrative information, i.e. which fish species and size classes were present in the ponds, but quantitative data was not available. The same applies to other prey categories (crayfish, reptiles, mammals, amphibians, birds and insects).

\subsection{Prey fish size selection}

Prey fish size selection was measured using Manly's selection index, which compares the proportional abundance of each salmonid size class recorded in the otter scat samples to the proportional abundance of the size classes in the studied streams (Manly et al., 2002). As quantitative data on prey availability existed only for salmonids, the index was solely calculated for salmonid size classes for every stream separately using both diet measures, RFO and BIO. We followed the design I protocol for calculating Manly's selection ratios $\left(w_{i}\right)$ and standardized selection ratio $\left(B_{i}\right)$ on the population level. If $w_{i}$ is significantly larger than one, the size class is used more than expected by chance, which indicates a preference for a size class. In contrast, values less than one (close to 0 ) indicate avoidance of a size class. If a size class is used in proportion to the availability in the environment, then the selection ratio $w_{i}=1$. With a value from 0 to 1 , the standardized selection ratio $\left(B_{i}\right)$ gives the estimated probability that a fish size class would be the next one selected if all size classes were equally available. We computed Manly's selection ratios using R3.4.2 statistic software (R Core Team, 2017) and the $R$ package adehabitatHS 0.3.12 (Calenge, 2006) with design I data type (Manly et al., 2002), and estimated significance of selection of a particular prey fish size by $\log$-likelihood $\chi^{2}$ test, using a Bonferroni corrected $\alpha$ level of 0.0167 .

\section{Results}

\subsection{Diet composition and spatial and seasonal variation in prey consumed}

A total of 2395 faecal samples were collected and analysed, of which $91 \%(n=2172)$ contained prey remains. The remaining samples were excretions of anal scent glands or intestine mucus, without prey remains. Sample sizes per study site and season are shown in Tables 1 and 2 . We identified a total of 12 different prey categories in the whole scat sample. Across all sites, fish dominated otter diet for both frequency and biomass based diet measures (mean RFO: $60 \%$, mean BIO: $77 \%$ ), followed by crayfish (mean RFO and BIO both 11\%) and amphibians (mean RFO: $11 \%$, mean BIO: $8 \%$ ). Significant deviations between the two methods were found within the category fish for salmonids and bullheads, as well as for insects $\left(\chi^{2}=28.2 ; \mathrm{df}=4\right.$; $P<0.001)$ : biomass of salmonids doubled relative to the observed frequency, whereas for bullheads the opposite pattern was found (mean RFO 26\%; mean BIO 7\%). The latter was also true for insects, where frequency based methods overestimated their proportion in otter diet relative to their biomass by a factor of 50 .

Within the prey category fish, on average salmonids (RFO: $29 \% \pm 1$ ) and bullheads (RFO: $26 \% \pm 12$ ) were consumed most frequently by otters (Fig. 2). In some cases, also other fish species represented a considerable proportion of otter diet (Tab. 2): grayling (O, spring; RFO: 4.1\%; BIO: 28.2\%), perch (Y, spring; RFO: 6.8\%; BIO: 5.7\%) and cyprinids (P, spring; RFO: $5.1 \%$; BIO: $7.3 \%$ ). Within the alternative prey categories (i.e. non-fish) amphibians (up to $26.2 \% \mathrm{RFO}, 21.8 \% \mathrm{BIO}$ in spring) and crayfish (up to $41.4 \%$ for RFO and BIO in summer) at least seasonally formed important prey resources. While mammals, reptiles and birds with $\leq 5 \%$ of RFO and BIO represented prey categories less consumed by otters in our study areas. Despite being frequently consumed, insects (e.g. beetles, dragonfly larvae) comprise a negligible component of the total ingested biomass in otter diet $(\leq 0.1 \%)$.

Values for trophic niche breadth ranged for the frequency based method from 0.13 to 0.42 , and from 0.03 to 0.19 for the relative biomass consumed (Tab. 3). Otters had the broadest niche at study site $\mathrm{Y}$ based on both diet analysis methods. Regardless of the locality, the trophic niche breadth was highest during spring.

In respect of spatial trophic niche overlap, Pianka's index ranged between 0.49 and 0.97 in terms of relative frequency of 
M. Sittenthaler et al.: Knowl. Manag. Aquat. Ecosyst. 2019, 420, 29

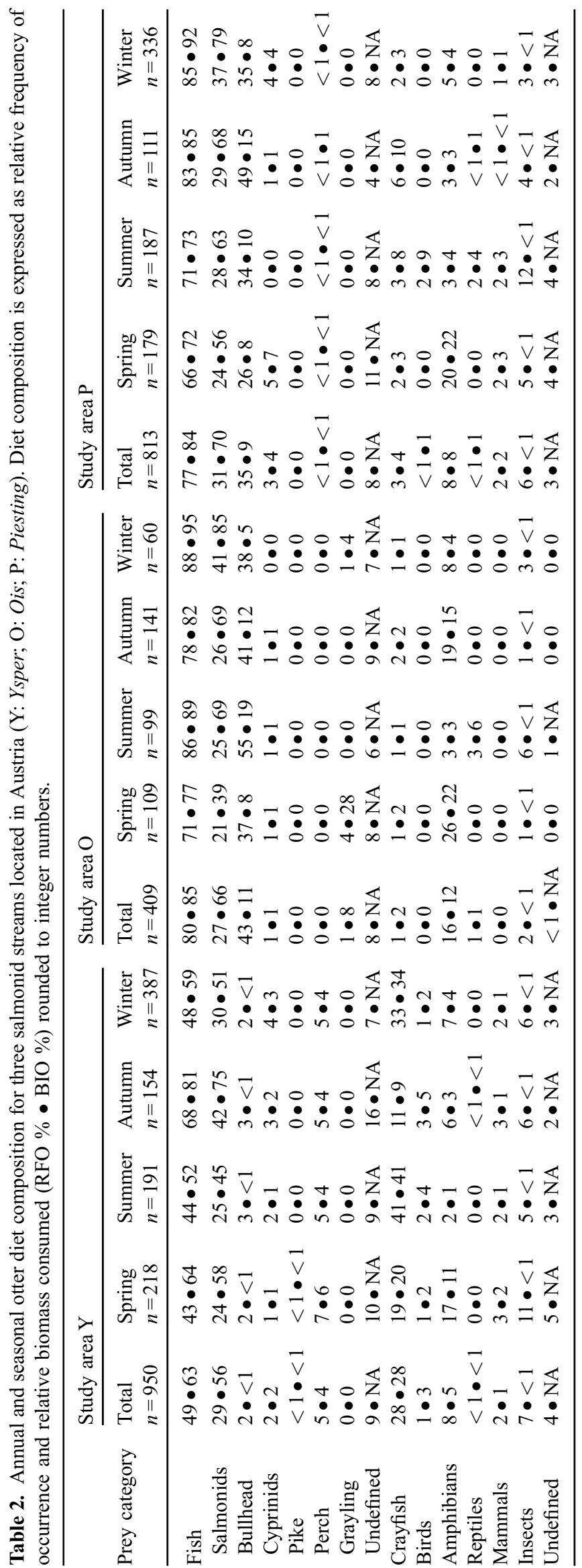




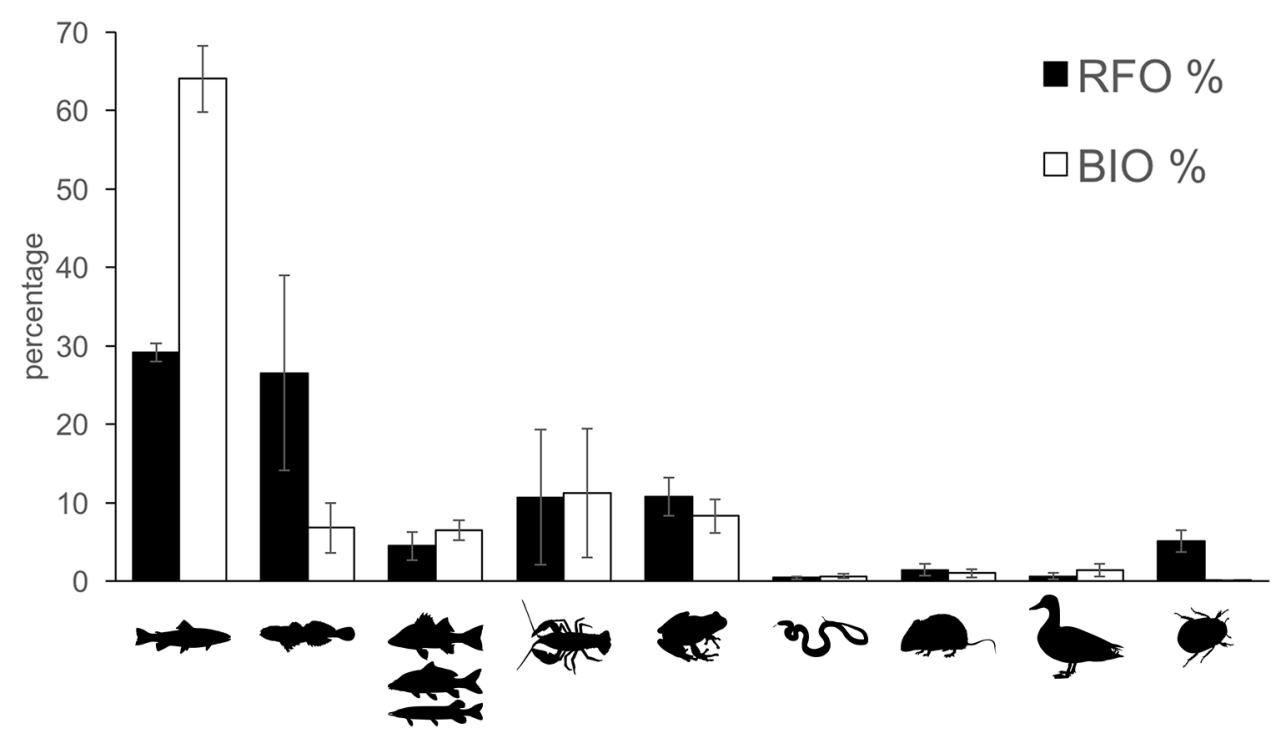

Fig. 2. Otter diet composition as percentage relative frequency of occurrence (RFO) and relative biomass $(\mathrm{BIO})$ in salmonid streams $(n=3)$. Bars show mean $\pm \mathrm{SD}$ (standard deviation). Prey categories from left to right: salmonids, bullhead, other fish, crayfish, amphibians, reptiles, mammals, birds and insects.

Table 3. Trophic niche breadth (Levins 1968) of otters at three salmonid streams (Y: Ysper; O: Ois; P: Piesting). Diet composition expressed as relative frequency of occurrence (RFO\%) and relative biomass consumed (BIO\%).

\begin{tabular}{lllllll}
\hline \multirow{2}{*}{ Study site Method (\%) } & \multicolumn{5}{c}{ Levins index of trophic niche breadth } \\
\cline { 2 - 7 } & & Spring & Summer & Autumn & Winter & Total \\
\hline \multirow{3}{*}{ Y } & RFO & 0.42 & 0.23 & 0.26 & 0.27 & 0.32 \\
& BIO & 0.12 & 0.13 & 0.06 & 0.12 & 0.12 \\
$\mathrm{O}$ & $\mathrm{RFO}$ & 0.22 & 0.13 & 0.19 & 0.16 & 0.19 \\
& $\mathrm{BIO}$ & 0.19 & 0.07 & 0.07 & 0.03 & 0.09 \\
$\mathrm{P}$ & $\mathrm{RFO}$ & 0.34 & 0.27 & 0.15 & 0.20 & 0.25 \\
& $\mathrm{BIO}$ & 0.13 & 0.10 & 0.08 & 0.04 & 0.07 \\
\hline
\end{tabular}

occurrence, and between 0.88 and 0.99 in terms of relative biomass (Tab. 4).

The results of the PRC showed that in terms of relative frequency of occurrence, only $14 \%$ of the total variance could be exclusively attributed to the variable season, whereas $56 \%$ could be attributed to the different localities and their interaction with season (Tab. 5). Eighty-eight percent of the variance explained by stream locality $\times$ season is displayed on the vertical axis in Figure 3 (a, c, e), showing differences in prey composition between the study sites. Figure 3 (b, d, f) shows the most dominant changes of prey species composition over time for the three studied streams relative to the respective control site in terms of biomass: about $9 \%$ of total variance was explained by season, and $36 \%$ by stream locality interacting with season, of which $70 \%$ is shown on the vertical axis of the PRC curves (Tab. 5). Monte Carlo permutations tests permuting whole time series indicated that the PRC diagram displayed a significant part of the stream variance (RFO: $F=80.51, P=0.001$; BIO: $F=22.11, P=0.001)$.
At stream $\mathrm{O}$ and stream $\mathrm{P}$, positive species weights indicated that throughout the year bullheads were much more abundant in otter diet (ranging from 37 to 55\% RFO for O and from 26 to $49 \%$ for P) compared to stream Y (2-3\% RFO) (Tab. 2; Fig. 3). In terms of proportion of consumed biomass, differences in bullheads became less important but still existed. However, at $\mathrm{Y}$ during all seasons crayfish played an important role in otter diet (RFO: 11-41\%; BIO: 9-41\%). In contrast, crayfish at O (RFO: $1-2 \%$; BIO: $1-2 \%$ ) and P (RFO: 2-6\%; BIO: $3-10 \%$ ) made up a minor part in otter diet. The negative weight of prey category salmonids and the shape of the curves (Fig. 3b, d, f) indicated that in summer and winter, salmonid biomass proportion in otter diet was higher for otters at stream P (summer: $63 \%$; winter: $79 \%$ ) and even higher at $\mathrm{O}$ (summer: 69\%; winter: $85 \%$ ) compared to $\mathrm{Y}$ (summer: $45 \%$; winter: $51 \%$ ).

Additionally, in terms of frequency, perch, mammals and insects contributed more to otter diet at $\mathrm{Y}$ compared to $\mathrm{O}$ and $\mathrm{P}$. In terms of biomass, besides perch also birds were more consumed by otters at stream Y. In contrast, amphibians and reptiles had a higher biomass proportion in otter diet at $\mathrm{P}$ and $\mathrm{O}$. With a value ranging from -0.5 to 0.5 , the remaining prey categories did not show a response to the pattern shown by the PRC.

For relative frequency of occurrence, differences in prey consumption between the study sites were significant over the year, tested by Monte Carlo permutation performed for each season $(P<0.014)$. Based on relative biomass diet measure, Monte Carlo tests per season revealed significant differences in prey composition between stream localities in spring, summer and winter $(P<0.013)$, but not in autumn $(P=0.492)$. This was mainly due to lesser consumption of crayfish and higher consumption of salmonids in autumn at stream Y.

Within all study sites and for both diet measures, we found significant seasonal differences. At $\mathrm{Y}$, crayfish consumption was significantly higher in summer and lowest in autumn 
Table 4. Trophic niche overlap (Pianka, 1973) for relative frequency of occurrence (RFO, below the diagonal) and relative biomass consumed (BIO, above the diagonal) for otter diet at three salmonid streams ( $\mathrm{Y}-$ Ysper, $\mathrm{O}-$ Ois, $\mathrm{P}-$ Piesting)

\begin{tabular}{llll}
\hline & \multicolumn{3}{l}{ Pianka index of food niche overlap } \\
\cline { 2 - 4 } Study site & $\mathrm{Y}$ & $\mathrm{O}$ & $\mathrm{P}$ \\
\hline $\mathrm{Y}$ & $\bullet$ & 0.88 & 0.91 \\
$\mathrm{O}$ & 0.49 & $\bullet$ & 0.99 \\
$\mathrm{P}$ & 0.60 & 0.97 & $\bullet$ \\
\hline
\end{tabular}

$\left(\mathrm{RFO}^{2}=47.4 ; \mathrm{BIO}^{2}=45.8 ; \mathrm{df}=15 ; P<0.001\right)$, while salmonid consumption was significantly higher in autumn. At stream $\mathrm{O}$, an increase in graylings was found in otter scats collected in spring, and a significantly higher proportion of salmonids in winter $\left(\mathrm{RFO}^{2}=56.2 ; \mathrm{BIO}^{2}=128.6\right.$; $\mathrm{df}=15$; $P<0.001)$. Significantly more reptiles, birds and insects have been eaten by otters in summer at stream $P\left({ }_{\mathrm{RFO}}{ }^{2}=59.4\right.$; $\left.\mathrm{BIO}^{2}=77.7 ; \mathrm{df}=15 ; P<0.001\right)$ and $\mathrm{O}\left({ }_{\mathrm{RFO}} \chi^{2}=56.2 ; \mathrm{BIO}^{2}=\right.$ $128.6 ; \mathrm{df}=15 ; P<0.001)$ compared to the rest of the year. In spring, the consumption of amphibians was significantly higher in all study sites and increased up to 10-fold of diet proportion compared to other seasons.

Seasonal trophic niche overlap within a study site ranged from 0.74 to 0.98 for RFO and from 0.76 to 0.99 in terms of BIO. For stream Y, it was highest between summer and winter $\left(O_{j k}=0.97\right.$ and 0.98 for RFO and $\mathrm{BIO}$, respectively) and lowest between summer and autumn $\left(O_{j k}=0.74\right.$ and 0.81 for RFO and BIO, respectively), mainly due to higher consumption of crayfish during summer. For study site, O seasonal niche overlap was lowest when comparing spring with other seasons $\left(O_{j k}=0.87\right.$ and 0.76 for RFO and BIO, respectively) due to high consumption of amphibians and graylings in spring. At stream $P$, pairwise comparisons resulted in a trophic overlap ranging from 0.94 to 0.99 in terms of relative biomass. Overlap decreased when comparing spring with other seasons concerning the frequency based method, mainly due to high consumption of amphibians in spring $\left(O_{j k}=0.85-0.91\right)$.

\subsection{Stream fish species composition and availability}

Electrofishing surveys and CPUE calculations showed that salmonids were the most abundant fish family: in terms of individuals per $100 \mathrm{~m}$ salmonid proportion ranged from $62.9 \%$ for stream $\mathrm{O}$ to $99.4 \%$ for stream $\mathrm{Y}$; regarding biomass, the proportion was even higher, ranging from $92.5 \%$ for stream $\mathrm{O}$ to $99.7 \%$ for stream $\mathrm{Y}$. Whereas at stream $\mathrm{O}$ and $\mathrm{P}$ besides brown trout also a considerable stock of rainbow trout occurred (up to one third of fish biomass), at stream Y, this species was represented by a few individuals only. A single specimen of brook trout (Salvelinus fontinalis) was caught at stream Y and $\mathrm{O}$; thus this species is not shown in Figure 4.

Small salmonid fish $(<120 \mathrm{~mm})$ were most abundant in stream Y (81.2\% of all fish caught), compared to 20.1 and $52.5 \%$ for stream $\mathrm{O}$ and $\mathrm{P}$, respectively, but became less important in terms of biomass prey availability in all three streams (Fig. 4). At stream Y and P, 16.5\% and 17.5\% of all caught salmonids were between 120 and $250 \mathrm{~mm}$ in length, representing $63 \%$ and $41.8 \%$, respectively, of total fish biomass. At stream $\mathrm{O}$, medium sized salmonids add up to $23.1 \%$ in terms of abundance and to a similar proportion in terms of biomass $(27.8 \%)$. The highest proportion of large salmonids, i.e. fish $>250 \mathrm{~mm}$ was detected for stream O $(15.6 \%$ of all individuals; $40.6 \%$ of biomass), followed by stream $\mathrm{P}$ ( $4.5 \%$ of all individuals; $42.9 \%$ of biomass). With $1.7 \%$ of all fish caught and $16.8 \%$ in terms of biomass, large fish were relatively less available in stream Y.

In addition, at stream $\mathrm{O}$ graylings contributed to prey availability for otters with 2 individuals per $100 \mathrm{~m}$ stream length, while they were not present in stream $Y$ and $P$. The proportion of bullheads at stream Y was low (one individual per $100 \mathrm{~m}$ ) compared to the limestone streams, where bullheads represent up to $36.4 \%$ of all fish caught. However, the high proportion of bullheads decreased to less than $5 \%$ when considering biomass availability.

Overall, the streams did not only differ in species composition and size class frequencies, but also in the total amount of prey fish availability: in total there was 3.2, 18.2 and $5.5 \mathrm{~kg}$ fish biomass per $100 \mathrm{~m}$ stream length of streams $\mathrm{Y}, \mathrm{O}$ and $\mathrm{P}$, respectively.

\subsection{Size selection of salmonids}

Concerning salmonid size classes, 13-38\% (RFO) and 1$7 \%$ (BIO) of all salmonids consumed by otters were smaller than $120 \mathrm{~mm}$, whereas proportions of medium salmonids ranged between 47 and 68\% (RFO), and between 39 and 54\% (BIO). For large salmonids, proportion values ranged between 10 and 19\% (RFO) and from 40 to 55\% (BIO) (Tab. 6).

In general, both diet measures revealed a similar picture of fish size selectivity. In Table 6 , we provide a complete list of Manly's selection ratios. Overall, with a significant selection ratio ranging from 0.259 and $0.692(P<0.001)$, we found that otters showed a marked avoidance of small salmonid fish. At stream Y, large fish were highly preferred (RFO: $w_{i}=11.854$ and BIO: $\left.w_{i}=3.310\right)$ by otters, even though they were relatively scarce in the environment. In terms of RFO, otters at $\mathrm{Y}$ showed a clear preference for medium-sized fish, while in terms of BIO, they tended to avoid them. If all salmonid size classes were equally available in stream $\mathrm{Y}$, fish of size class $\mathrm{C}$ $(>250 \mathrm{~mm})$ would be taken 25 times more than small fish and 4 times more than medium-sized fish in terms of RFO, and 13 and 5 times more in terms of biomass, respectively (see $B_{i}$ in Tab. 6). In contrast to stream $Y$, otters at streams $O$ and $P$ showed a similar selectivity pattern for salmonid size classes: while otters tended to prefer medium sized salmonids, there seemed to be no selectivity for fish of size class C, indicating a proportional use to their availability (RFO Ois: $w_{i}=0.778$, $P=0.074$; RFO Piesting: $\left.w_{i}=1.651, P=0.035\right)$. In terms of biomass, with selection ratios significantly below 1 , large fish were even avoided by otters in both streams. However, for stream $\mathrm{P}$, the selection ratio and the upper confidence limit were very close to $1\left(w_{i}=0.857\right)$, suggesting that otters ingested fish larger than $250 \mathrm{~mm}$ in proportion to their availability. For stream $\mathrm{O}$, confidence intervals of fish size class $\mathrm{A}$ and $\mathrm{C}$ were overlapping in both measures, RFO and BIO (Fig. 5). This means that they had a similar chance to be eaten by an otter, while the chance for medium sized fish was 
Table 5. Percentage of the total variance that can be attributed to season and stream locality for otter diet composition expressed in relative frequency of occurrence (RFO\%) and biomass (BIO\%) revealed by Principal response curve (PRC) analysis.

\begin{tabular}{|c|c|c|c|c|c|}
\hline \multirow[t]{2}{*}{ Dataset } & \multicolumn{2}{|c|}{$\%$ variance accounted for by } & \multirow{2}{*}{$\begin{array}{l}\% \text { variance explained by stream captured by } \\
1 \mathrm{st} \text { PRC }\end{array}$} & \multicolumn{2}{|c|}{ Permutation significance } \\
\hline & Season & Stream $\times$ season & & All axes & 1st axis \\
\hline RFO\% & 14.10 & 56.33 & 88.02 & 0.001 & 0.001 \\
\hline $\mathrm{BIO} \%$ & 9.45 & 35.81 & 70.42 & 0.001 & 0.001 \\
\hline
\end{tabular}

\section{RFO}
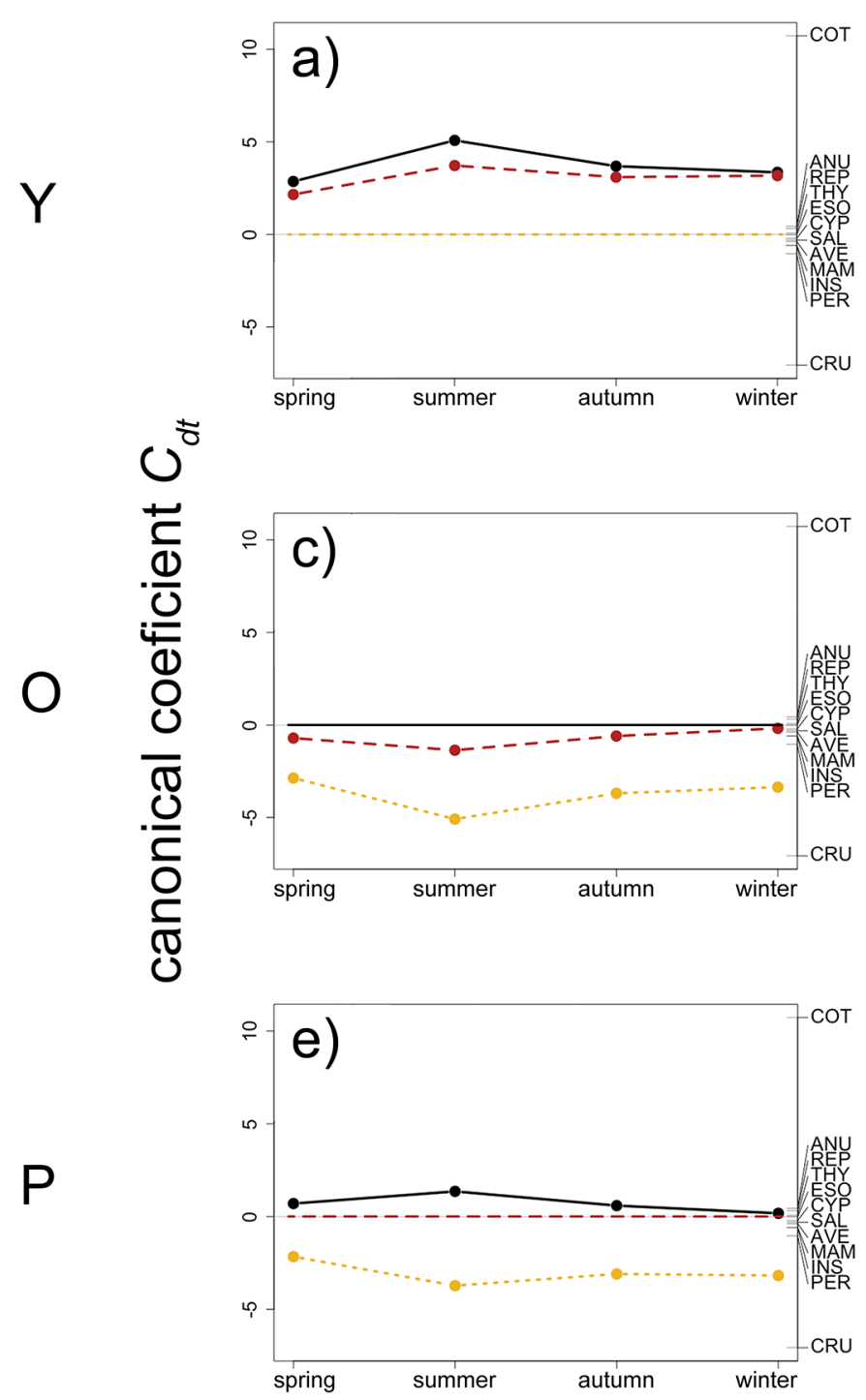

$\mathrm{BIO}$
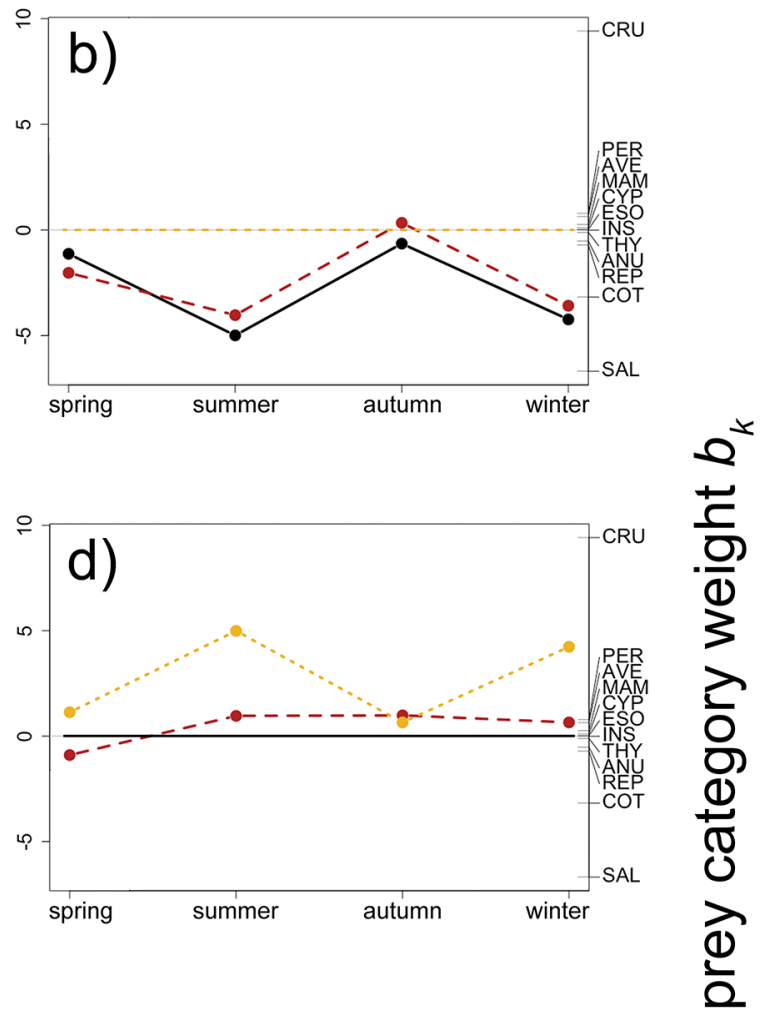

\section{seasons}

Fig. 3. First principal response curves (PRC) showing effects of season and study site on otter diet composition expressed as relative frequency of occurrence (RFO; a, c, e) and relative biomass (BIO; b, d, f). In every line, the reference site changes (a, b: reference Ysper; c, d: reference Ois; e, f: reference Piesting). Dotted yellow lines: Ysper; solid black lines: Ois; dashed red line: Piesting. Prey category weights $\left(b_{k}\right)$, shown on the right $y$-axis, can be interpreted as the affinity of each category to the Principal response curves and have the same numerical scale as the left $y$ axis $\left(c_{d t}\right)$. ANU: amphibians; AVE: birds; COT: bullhead; CRU: crayfish; CYP: cyprinids; ESO: pike; INS: insects; MAM: mammals; PER: perch; REP: reptiles; SAL: salmonids; THY: grayling. 

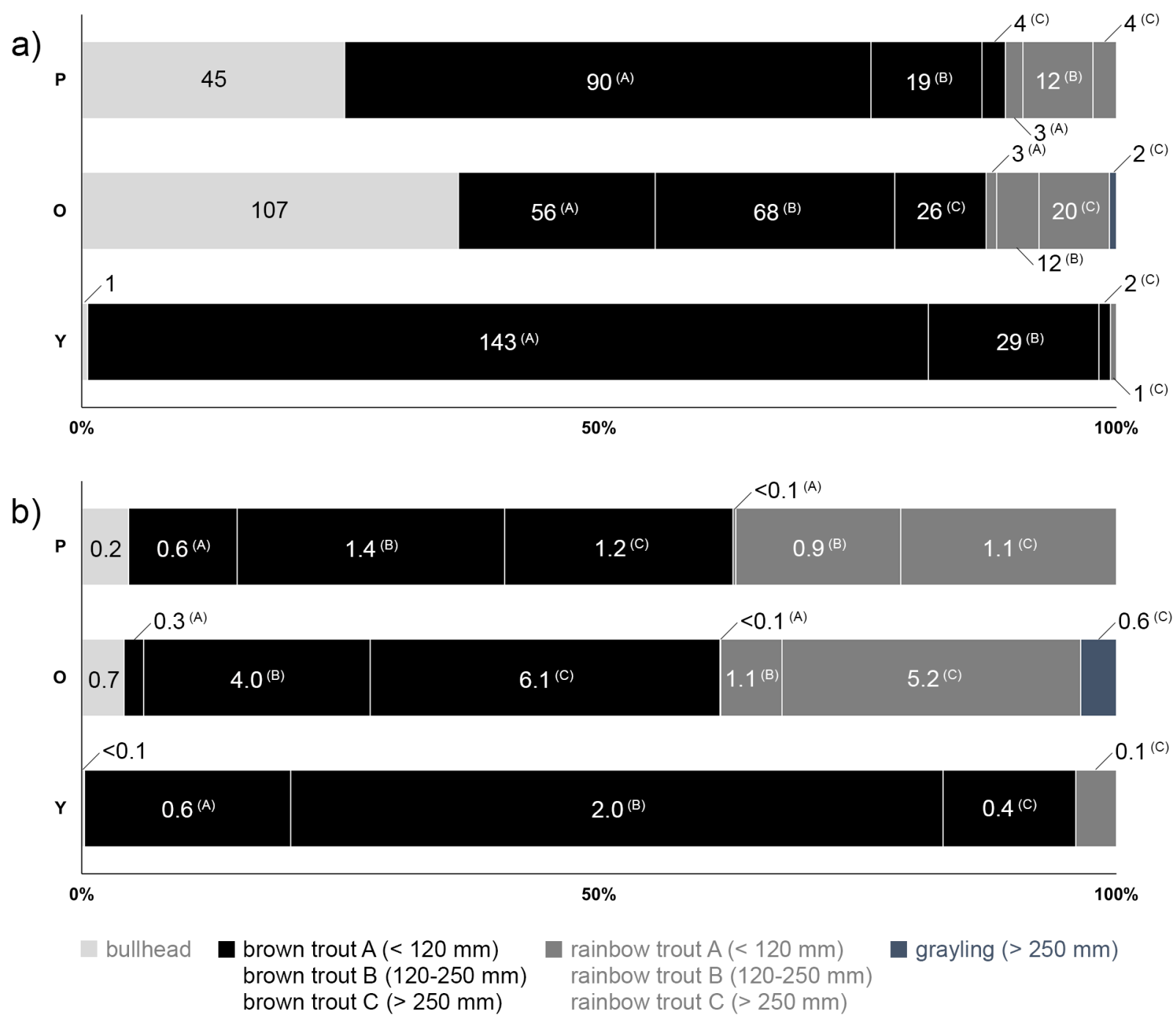

Fig. 4. Relative prey fish availability in terms of (a) abundance given as individuals and (b) biomass in kilogram per $100 \mathrm{~m}$ stream length for the streams Ysper (Y), Ois (O), and Piesting (P). Figures in the bars indicate absolute values (individuals or $\mathrm{kg}$ ) per $100 \mathrm{~m}$ stream length.

up to 4 times higher $\left(B_{i}=0.57\right)$ compared to fish of size class A and $\mathrm{C}$. At stream $\mathrm{P}$, medium and large fish had overlapping confidence intervals in terms of RFO (Fig. 5). Compared to fish smaller than $120 \mathrm{~mm}$, they would be taken 2 to 3 times more frequently, if all size classes were equally available for otters.

\section{Discussion}

Foraging decisions and trophic niche width of predators are strongly determined by the presence, abundance and behaviour of prey groups through time and space, resulting either in a more opportunistic or a selective feeding strategy of the consumer following the optimal foraging theory (Stephens and Krebs, 1986; Begon et al., 2006).

We found that otters in upper reaches of three temperate salmonid streams in Lower Austria occupy a relatively narrow niche, reflecting the limited number of prey groups naturally occurring in these habitats with fish communities dominated by salmonid species. This is in accordance with Brzezinski et al. (2006) reporting a greater trophic niche breadth for otters in lowland rivers compared to upland streams. As the streams under study belong to the epi- and metarhithral region and thus generally provide similar conditions concerning otter prey fish availability, the trophic niche overlap of otters between the streams was high, especially in terms of consumed biomass. Nevertheless, otter diet composition and salmonid size selection varied significantly within and between the streams, which can be related to variations in prey community composition as a function of seasonal prey activity patterns or human activities and habitat alterations, as well as to streamspecific habitat characteristics, which we discuss below.

As reviewed by Krawczyk et al. (2016), regardless of type of waterbody fish are the primary prey category in temperate regions throughout Europe (Clavero et al., 2003; Kruuk, 2006; Lanszki et al., 2016). This is also in line with our results for otters in salmonid streams: overall, otters fed predominantly on fish with salmonids mostly dominating otter diet throughout the year, at least in terms of ingested biomass. Although salmonids were the dominating prey fish group in the environment of our study areas and provide a high-energy intake for a predator, they are fast-swimming species, and 
Table 6. Manly's selection ratios and indices for salmonid fish size classes in the diet of otters in three salmonid streams (Y: Ysper; O: Ois; P: Piesting). Significant values are set in bold, considering a Bonferroni correction.

\begin{tabular}{|c|c|c|c|c|c|c|c|c|}
\hline Study site & Diet measure & Fish size class & $\begin{array}{l}\text { Proportion } \\
\text { used }\end{array}$ & $\begin{array}{l}\text { Proportion } \\
\text { available }\end{array}$ & $\begin{array}{l}\text { Selection } \\
\text { ratio } w_{i}\end{array}$ & $w_{i} \mathrm{SE}$ & $P$-value & $\begin{array}{l}\text { Standardized } \\
\text { index } B_{i}\end{array}$ \\
\hline \multirow{6}{*}{ Y } & \multirow{3}{*}{$\mathrm{RFO} \%$} & $\mathrm{~A}<120 \mathrm{~mm}$ & 0.38 & 0.82 & 0.465 & 0.024 & $<0.001$ & 0.031 \\
\hline & & B $120-250 \mathrm{~mm}$ & 0.47 & 0.17 & 2.780 & 0.220 & $<0.001$ & 0.184 \\
\hline & & $\mathrm{C}>250 \mathrm{~mm}$ & 0.15 & 0.01 & 11.854 & 3.326 & 0.001 & 0.785 \\
\hline & \multirow{3}{*}{$\mathrm{BIO} \%$} & $\mathrm{~A}<120 \mathrm{~mm}$ & 0.05 & 0.20 & 0.259 & 0.006 & $<0.001$ & 0.062 \\
\hline & & B $120-250 \mathrm{~mm}$ & 0.39 & 0.63 & 0.622 & 0.005 & $<0.001$ & 0.148 \\
\hline & & $\mathrm{C}>250 \mathrm{~mm}$ & 0.55 & 0.17 & 3.310 & 0.054 & $<\mathbf{0 . 0 0 1}$ & 0.790 \\
\hline \multirow{6}{*}{$\mathrm{O}$} & \multirow{4}{*}{$\mathrm{RFO} \%$} & $\mathrm{~A}<120 \mathrm{~mm}$ & 0.13 & 0.32 & 0.396 & 0.078 & $<0.001$ & 0.144 \\
\hline & & B $120-250 \mathrm{~mm}$ & 0.68 & 0.43 & 1.570 & 0.097 & $<0.001$ & 0.572 \\
\hline & & $\mathrm{C}>250 \mathrm{~mm}$ & 0.19 & 0.24 & 0.778 & 0.125 & 0.074 & 0.283 \\
\hline & & $\mathrm{A}<120 \mathrm{~mm}$ & 0.01 & 0.02 & 0.692 & 0.047 & $<0.001$ & 0.220 \\
\hline & \multirow[t]{2}{*}{$\mathrm{BIO} \%$} & B $120-250 \mathrm{~mm}$ & 0.54 & 0.30 & 1.792 & 0.016 & $<\mathbf{0 . 0 0 1}$ & 0.570 \\
\hline & & $\mathrm{C}>250 \mathrm{~mm}$ & 0.45 & 0.68 & 0.659 & 0.006 & $<\mathbf{0 . 0 0 1}$ & 0.210 \\
\hline \multirow{6}{*}{$\mathrm{P}$} & \multirow{4}{*}{$\mathrm{RFO} \%$} & $\mathrm{~A}<120 \mathrm{~mm}$ & 0.38 & 0.66 & 0.577 & 0.034 & $<\mathbf{0 . 0 0 1}$ & 0.142 \\
\hline & & B $120-250 \mathrm{~mm}$ & 0.52 & 0.28 & 1.852 & 0.130 & $<\mathbf{0 . 0 0 1}$ & 0.454 \\
\hline & & $\mathrm{C}>250 \mathrm{~mm}$ & 0.10 & 0.06 & 1.651 & 0.309 & 0.035 & 0.405 \\
\hline & & $\mathrm{A}<120 \mathrm{~mm}$ & 0.07 & 0.11 & 0.639 & 0.016 & $<0.001$ & 0.233 \\
\hline & \multirow[t]{2}{*}{$\mathrm{BIO} \%$} & B $120-250 \mathrm{~mm}$ & 0.53 & 0.42 & 1.252 & 0.010 & $<0.001$ & 0.456 \\
\hline & & $\mathrm{C}>250 \mathrm{~mm}$ & 0.40 & 0.47 & 0.857 & 0.008 & $<\mathbf{0 . 0 0 1}$ & 0.312 \\
\hline
\end{tabular}

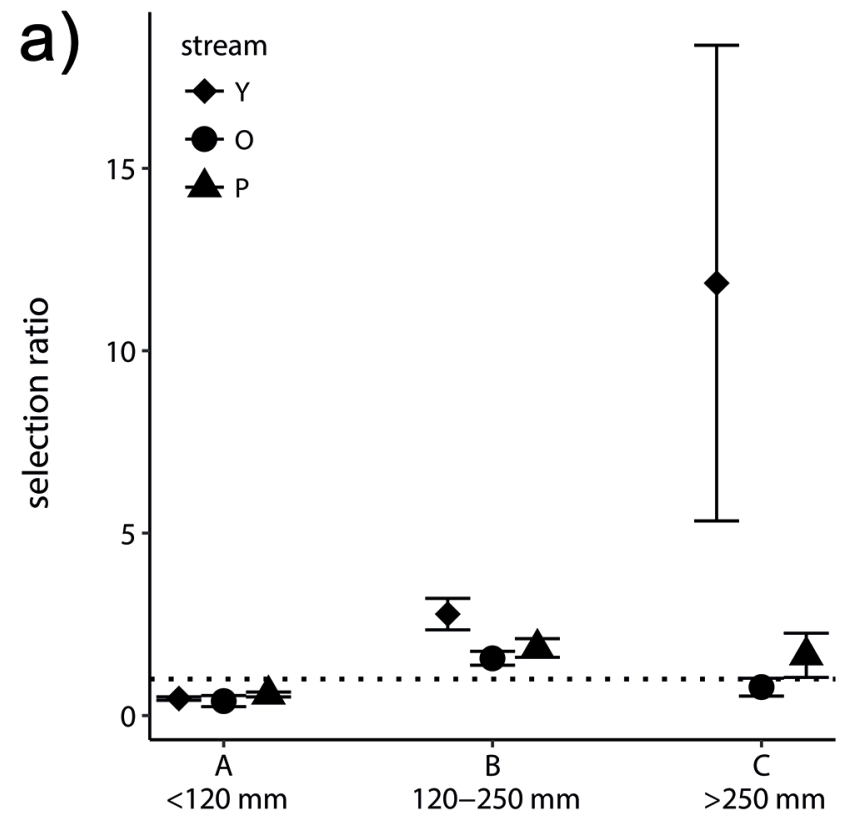

salmonid size class

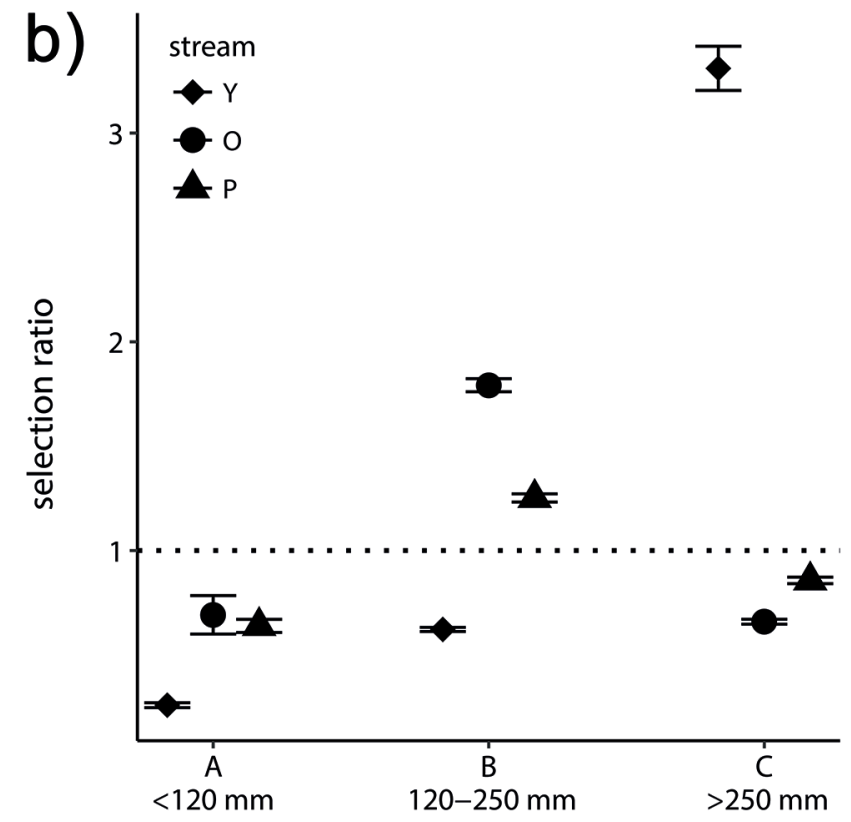

salmonid size class

Fig. 5. Manly's selection ratios $w_{i}$ for three size classes of salmonid fish in otter diet at three salmonid streams (Y: Ysper; O: Ois; P: Piesting) for relative frequency of occurrence (a) and relative biomass (b). Values above the dotted line indicate a preference, while values below indicate an avoidance. Error bars represent 95\% confidence interval.

preying on them costs much energy to predators (Day et al., 2015). To optimize their feeding strategy, wherever and whenever it becomes more profitable, otters seemed to complement their diet with alternative prey resources of lower energetic value if they become highly available and require less energy to catch (Clavero et al., 2003). Hence, other fish species (bullheads, pond fish) and other prey groups, most notably crayfish and amphibians, locally and/or seasonally became important key resources in our study areas according to local and seasonal prey availability and vulnerability. This 
dietary plasticity (Reid et al., 2013) could be either a consequence of varying availability of primary prey, or due to taking advantage of highly abundant secondary prey (Clavero et al., 2003) or a combination of both factors, leading to a more opportunistic feeding behaviour of the otter.

\subsection{Local prey availability}

The high crayfish consumption by otters throughout the year at stream Y, on one hand, may be related to lower total prey fish availability compared to the other streams. On the other hand, high crayfish consumption at stream Y may also be related to high signal crayfish abundance in this area due to stocking of this highly invasive, non-native crayfish species in numerous ponds nearby stream $\mathrm{Y}$ in former times (personal communication) and their subsequent expansion to stream habitats. It is known that otters shift their diet after biological invasions of freshwater systems by non-native, invasive species (Balestrieri et al., 2013). For example, Barrientos et al. (2014) found that otters in Mediterranean streams adapted their trophic niche by incorporating non-native food sources and the red swamp crayfish (Procambarus clarkii) even became the most important prey item in those areas. Crayfish provide about one third less of energy intake compared to fish of similar dimensions (Beja, 1996; Ruiz-Olmo and Jiménez, 2009), they have a high proportion of non-consumable parts and require relatively long handling times by otters (Watt, 1993). The consumption rate of crustaceans might be densitydependent because a high density of secondary prey leads to shorter searching times and higher attack success rates, which affect profitability for otters. The same may be applicable for bullheads. As slow-moving, bottom-dwelling fish species rarely exceeding $150 \mathrm{~mm}$ in total length and rarely travelling more than a hundred meters in their life (Tudorache et al., 2008), bullheads may be easy to predate by otters and, if available, they are known to be consumed in large numbers (Grant and Harrington, 2015). Based on our CPUE calculations of bullhead abundance per $100 \mathrm{~m}$ stream length, there were high differences between the three study areas (Y: 1 individual per $100 \mathrm{~m}$ compared to 45 and 107 individuals per $100 \mathrm{~m}$ for $\mathrm{P}$ and $\mathrm{O}$, respectively). Some studies suggested a selection of fish species according to their swimming abilities with slow-moving species being preferred by otters (Taastrom and Jacobsen, 1999; Day et al., 2015). Here, we only have semi-quantitative data on bullhead abundance; nevertheless, they indicate that bullhead consumption by otters generally reflected bullhead abundance when comparing our studied streams.

As otters are food-limited (Kruuk et al., 1993; Ruiz-Olmo et al., 2001, 2011), the relation between predator densities and the total amount of preferred prey (fish) available may also play a role in foraging decisions, as shown by Smith et al. (2015) for female California sea otters (Enhydra lutris). At stream Y, we had 1.5 times higher otter density compared to stream $\mathrm{O}$ (Sittenthaler et al., unpublished data), whereas stream fish availability was 3 to 6 times higher at O compared to $\mathrm{P}$ and $\mathrm{Y}$, respectively. Intraspecific competition therefore may be higher for primary prey (fish, salmonids) at stream Y, which may also lead to higher diversification of otter diet and inclusion of alternative prey as key resource (Remonti et al.,
2009), as also indicated by higher trophic niche breadth values (Kloskowski et al., 2013).

\subsection{Seasonal prey availability and vulnerability}

Besides local patterns of prey availability and predator densities, also seasonal activity patterns of prey are assumed to be crucial drivers of feeding behavior of otters (e.g. Day et al., 2015). In spring amphibians migrate to and congregate at spawning waters, where they become easily accessible and profitable prey for otters, although the energetic value of amphibians is lower compared to that of fish (Nelson and Kruuk, 1997). Otters preying on large quantities of spawning amphibians is a phenomenon observed across a wide geographical range and different aquatic habitats throughout Europe (Clavero et al., 2003; Krawczyk et al., 2016), which we here documented also for upper reaches of temperate salmonid streams.

Further, in autumn at stream Y, we observed a shift from highly abundant secondary prey (crayfish) to salmonids (increase of $17-30 \%$ compared to other seasons). This trade-off between fish and crayfish consumption may be since brown trout have their spawning season during this time of the year. Like in other species, reproducing trout are exposed to increased predation due to conspicuousness (Magnhagen, 1991). In our case, it seemed that the role of a highly abundant alternative prey lost in importance, as soon as high-energy value prey became more accessible and easier to catch. Crowley et al. (2013) and Day et al. (2015) also reported an increase of salmonid presence in North American river otter (Lontra canadensis) scats during spawning period of brown trout. In temperate zones, brown trout in crystalline streams have their spawning peak in October, while in limestone streams, they have it in December (Unfer et al., 2011). The salmonid consumption in the other two streams was also elevated, but only significantly different from other seasons at stream $\mathrm{O}$ during winter, coinciding with spawning season of brown trout in those areas. We assume that spawning season might also explain the high consumption of grayling at stream $\mathrm{O}$ during spring. Graylings are fast-moving fish using open water zones in deep pools of running waters, where they usually are difficult to catch and probably avoided by otters as shown by Lanszki et al. (2001) for fish using open water zones in ponds. However, from March to May graylings also frequent shallow water zones to lay their eggs and during this time mature graylings $(>250 \mathrm{~mm})$ become a profitable prey for otters, reaching nearly $30 \%$ of total biomass consumed in spring at stream $\mathrm{O}$.

\subsection{Salmonid size selection}

The above examples support the assumption that otters are opportunistic feeders, shifting their diet and using different prey categories to maximize their foraging efficiency according to the optimal foraging theory. Focusing on prey fish size selection within the category of salmonids, however, frequency distribution and biomass proportions of consumed salmonids did not reflect the proportions of salmonid size class availability in streams, indicating a selective feeding behaviour in otters. Contrary to our findings, Kortan et al. (2010) reported 
that otters capture brown trout of all size classes in similar proportions to their abundance in a salmonid stream in the Czech Republic. Unfortunately, they did not report size selection indices and test results for brown trout separately, but for all fish species together. Here, in relation to fish size frequency distribution, otters captured less salmonids smaller than $120 \mathrm{~mm}$ in total length. In near-natural, fast-flowing streams providing sufficient shelter and means of escape for small salmonids, preying on them seemed to be too costly for otters in relation to energy intake, although they were available in high numbers. At stream Y with $1.7 \%$ of all fish and $16.8 \%$ in terms of total biomass, large salmonids were relatively less abundant. But there was a strong selectivity for salmonids $>250 \mathrm{~mm}$, while at stream $\mathrm{O}$ and $\mathrm{P}$, they were consumed according to availability (in terms of relative frequency) or even avoided (in terms of relative biomass). We assume that availability of large salmonids at stream Y did not reach the critical threshold beyond which hunting them would not be profitable anymore, i.e. the required energy expenditure to hunt large salmonids, which were available at low densities at stream Y, in relation to the energy intake was still in balance. Day et al. (2015) suggested that besides seasonality, abundance, agility and life history of prey, the habitat of prey is an important driver in otter prey selection. Hence, we hypothesize that selection against larger salmonids may be due to higher stream dimensions (i.e. discharge, depth, width) and specifically the occurrence of deep pools in stream $\mathrm{O}$ and $\mathrm{P}$ (Stöger, 2016), providing salmonids a higher chance to escape a predator attack. Hence, although large fish provide a higher energy intake, in larger streams, they have a comparable probability to be preyed on as small salmonids, as indicated by selection indices (Tab. 6). Mid-sized salmonids, on the other hand, on average inhabit shallower water zones (Armstrong et al., 2003), where predation becomes again profitable, and a positive selection could be observed (except for stream Y in terms of biomass, assumingly due to a high preference of large salmonids and compensation due to crayfish). Almeida et al. (2012), who studied scent marking and resource use in Mediterranean streams, also suggested that otters prefer to forage in shallow locations where fishing is easier. Hence, the profitability of preying on large fish at streams of more than a few meters of width and a large number of deep pools is probably limited by the disproportionate time and energy costs for pursuing them. The effect of microhabitat selection among fish species and consequently their susceptibility to otter predation was also discussed in context with selective feeding behaviour of otters by Remonti et al. (2010) for streams with a cyprinid fish composition. Therefore, stream-specific habitat characteristics and consequently vulnerability of aquatic prey might strongly influence searching and handling times as well as attack success rate for fast-swimming salmonids.

\subsection{Human-wildlife conflicts in salmonid streams}

In Central Europe, as in many other countries within otter species' distribution range, conflicts between otter conservation and fisheries are far from being solved, often resulting in illegal killings of otters and threatening otter populations once again (Roos et al., 2015). After a few years of de novo coexistence between fish-eating predators and prey fish populations in regions, where predators have been extinct, it is important to gather knowledge on predator diets and potential drivers of prey selection to be able to estimate the potential impact of fish-eating predators on hatchery fish, but also on natural fish stocks, as we provided here for upper reaches of salmonid streams.

Due to an opportunistic feeding behaviour, seasonally and locally non-fish prey categories and fish species without potential sport angling value were key resources in otter diet in our study. Specifically, these species accounted for 49 to $63 \%$ of the otter diet in terms of frequency and from 26 to $40 \%$ in terms of biomass throughout the year. Nevertheless, the importance of salmonid species in the otter diet in upper regions of salmonid streams, where prey fish spectrum is naturally limited to a few species and dominated by trout, is unquestioned (with year-round proportions of biomass ranging from 56 to $70 \%$, of which up to $55 \%$ were from fish of catchable size). In line with this, Kruuk et al. (1993) showed in their study, that up to $95 \%$ of all spraints contained salmonid remains. This is in contrast to streams where fish species availability is more diverse (e.g. lowland streams). In those areas, otters rarely consumed species and fish sizes that are also preferred by anglers (Grant and Harrington, 2015; Britton et al., 2017; Lyach and Cech, 2017).

Within the category of salmonid fish, our results suggest a selective feeding behaviour of otters in salmonid streams. In particular, otters demonstrated avoidance of small salmonids and an increase of preference of large salmonids with decreasing river dimension and the number of deep pools. Hence, the picture was not the same for all three streams investigated, highlighting the effect of mesohabitat characteristics and local conditions of an area.

For an understanding of the otter's top-down effects on the aquatic ecosystem, one has also to keep in mind that the majority of riverine habitats and fish populations in Central Europe are affected by anthropogenic actions. Habitat loss and alteration, hydrologic modifications and loss of lateral and longitudinal connectivity are major stressors for aquatic organisms (Stendera et al., 2012; Schinegger et al., 2012, 2016) and reduce the carrying capacity of streams. Also recreational activities, including the exploitation of fish stocks by angling put pressure on fish populations (Arlinghaus et al., 2002; Lewin et al., 2006; Cowx, 2015). Furthermore, upper reaches of salmonid streams might gain importance as recruitment and refuge areas for cold-water species with high oxygen needs facing future changes of temperature regimes due to climate change (Pletterbauer et al., 2015). We therefore expect that human-otter conflicts will intensify in small streams.

In the upper and lower trout region, cover and escape possibilities for fish are either naturally limited and/or habitat quality has decreased drastically due to anthropogenic actions. Within these areas, otters might be capable of keeping fish stocks at a relatively low level regarding biomass and abundance. If we assume that stream-specific habitat conditions and variation in local prey opportunities have a strong influence on prey selection of otters, then one-size-fitsall fisheries management strategies may lead to unintended consequences in many streams. For example, the widely distributed management strategy of stocking fish, either for conservation purposes or to attract anglers, must be critically 
scrutinized if deficits in habitat quality remain. Contrary to the management aim, the presence of stocked fish may attract additional fish predators to the site, e.g. great cormorants (Phalacrocorax carbo) (see also Weber and Fausch, 2003 and literature therein; Stewart et al., 2005).

Detailed knowledge about otter-prey interactions is needed to inform management of conflicts involving fisheries and piscivores. In particular, conservation and fisheries management practices must account for varying local conditions including anthropogenic pressures and stream morphology. Our study increases understanding about complex trophic interactions in streams of varying size and watershed characteristics, which builds on the evidence base for new legal frameworks to enable co-existence between apex predators, prey and human interests in diverse contexts across Central Europe.

\section{Supplementary Material}

Table S1. Species and site specific length-weight regression formulae (LT= total fish length in $\mathrm{mm}, \mathrm{W}=$ weight in $\mathrm{g}$ ) for biomass intake calculations.

Fig. S1. Length-frequency diagram of salmonid fish (brown trout and rainbow trout) in River Ysper based on electrofishing data.

Fig. S2. Length-frequency diagram of salmonid fish (brown trout and rainbow trout) in River Piesting based on electrofishing data.

Fig. S3. Length-frequency diagram of salmonid fish (brown trout and rainbow trout) and grayling in River Ois based on electrofishing data.

Fig. S4. Length-frequency diagram of bullheads in River Ysper based on electrofishing data.

Fig. S5. Length-frequency diagram of bullheads in River Piesting based on electrofishing data.

Fig. S6. Length-frequency diagram of bullheads in River Ois based on electrofishing data.

The Supplementary Material is available at https://www.kmaejournal.org $/ 10.1051 / \mathrm{kmae} / 2019020 / \mathrm{olm}$.

Acknowledgements. We thank Kathrin Heissenberger, Eva Schöll, Michaela Bodner and Christoph Leeb for assistance in the field. For helping with graphical design, we thank Christian Bartl. We are grateful to Brady Mattsson for English language revision and helpful comments on the manuscript. Silhouettes in Figure 2 are partly provided by Bob Comix and Natasha Sinegina. Samples and data on fish stocks were collected within studies funded by the Fisheries Association of Lower Austria and its Regional Fishing Associations (I-V).

\section{References}

Almeida D, Barrientos R, Merino-Aguirre R, Angeler DG. 2012. The role of prey abundance and flow regulation in the marking behaviour of Eurasian otters in a Mediterranean catchment. Anim Behav 84: 1475-1482.

Almeida D, Rodolfo N, Sayer CD, Copp GH. 2013. Seasonal use of ponds as foraging habitat by Eurasian otter with description of an alternative handling technique for common toad predation. Folia Zool 62: 214-221.
Araújo MS, Bolnick DI, Layman CA. 2011. The ecological causes of individual specialisation. Ecol Lett 14: 948-958.

Arlinghaus R, Mehner T, Cowx IG. 2002. Reconciling traditional inland fisheries management and sustainability in industrialized countries, with emphasis on Europe. Fish Fish 3: 261-316.

Armstrong JD, Kemp PS, Kennedy GJA, Ladle M, Milner NJ. 2003. Habitat requirements of Atlantic salmon and brown trout in rivers and streams. Fish Res 62: 143-170.

Balestrieri A, Remonti L, Vezza P, Prigioni C, Copp GH. 2013. Do non-native fish as prey favour the conservation of the threatened indigenous Eurasian otter? Freshwater Biol 58: 995-1007.

Barrientos R, Merino-Aguirre R, Fletcher DH, Almeida D. 2014. Eurasian otters modify their trophic niche after the introduction of non-native prey in Mediterranean fresh waters. Biol Invasions 16: 1573-1579.

Begon M, Townsend CR, Harper JL. 2006. Ecology: from individuals to ecosystems, 4th ed. Oxford: Blackwell Publishing, $750 \mathrm{p}$.

Beja PR. 1996. An analysis of otter Lutra lutra predation on introduced American crayfish Procambarus clarkii in Iberian streams. J Applied Ecol 33: 1156-1170.

Blanco-Garrido F, Prenda J, Narvaez M. 2008. Eurasian otter (Lutra lutra) diet and prey selection in Mediterranean streams invaded by centrarchid fishes. Biol Invasions 10: 641-648.

BMLFUW. 2015. Nationaler Gewässerbewirtschaftungsplan 2015. Vienna: Austrian Ministry of Agriculture, Forestry, Environment and Water Management, $358 \mathrm{p}$.

Britton JR, Berry M, Sewell S, Lees C, Reading P. 2017. Importance of small fishes and invasive crayfish in otter Lutra lutra diet in an English chalk stream. Knowl Manag Aquat Ecosyst 418: 13.

Brzezinski M, Romanowski J, Kopczynski L, Kurowicka E. 2006. Habitat and seasonal variations in diet of otters, Lutra lutra in eastern Poland. Folia Zool 55: 337-348.

Calenge C. 2006. The package "adehabitat" for the R software: a tool for the analysis of space and habitat use by animals. Ecol Model 197: 516-519.

Carss DN. 1995. Foraging behaviour and feeding ecology of the otter Lutra lutra: a selective review. Hystrix 7: 179-194.

Carss DN, Parkinson SG. 1996. Errors associated with otter Lutra lutra faecal analysis. 1: assessing general diet from spraints. J Zool (Lond) 238: 301-317.

Carter N, Linnell J. 2016. Co-adaption is key to coexisting with large carnivores. Trends Ecol Evol 31: 575-578.

CEN (European Committee for Standardization). 2003. Water quality-sampling of fish with electricity (European Standard EN 14011:2003). Brussels, Belgium: CEN.

Chapron G, Kaczensky P, Linnell JDC, et al. 2014. Recovery of large carnivores in Europe's modern human-dominated landscapes. Science 346: 1517-1519.

Clavero M, Prenda J, Delibes M. 2003. Trophic diversity of the otter (Lutra lutra L.) in temperate and Mediterranean freshwater habitats. J Biogeogr 30: 761-769.

Clavero M, Prenda J, Delibes M. 2004. Influence of spatial heterogeneity on coastal otter (Lutra lutra) prey consumption. Ann Zool Fennici 41: 551-561.

Conroy JWH, Watt J, Webb JB, Jones A. 2005. A guide to the identification of prey remains in otter spraint. London: The Mammal Society, 48 p.

Crowley S, Johnson CJ, Hodder CP. 2013. Spatio-temporal variation in river otter (Lontra canadensis) diet and latrine site activity. Ecoscience 20: 28-39.

Cowx IG. 1991. Catch effort sampling strategies - Their application in freshwater fisheries management. Oxford: Fishing News Books, Blackwell Scientific Publications, 432 p. 
Cowx IG. 2015. Characterisation of inland fisheries in Europe. Fisheries Manag Ecol 22: 78-87.

Czernik M, Kowalczyk R, Zalewski A. 2016. Spatio-temporal variation of predator diet in a rural habitat: stone martens in the villages of Bialowieza forest. Mammal Res 61: 187-196.

Day CC, Westover MD, Mcmillan BR. 2015. Seasonal diet of the northern river otter (Lontra canadensis): what drives prey selection? Can J Zool 93: 197-205.

De La Hey S. 2008. The importance of birds in the diet of otter Lutra lutra on Shapwick Heath. Biosci Horizons 1: 143-147.

Erlinge S. 1968. Food studies on captive otters Lutra lutra L. Oikos 19: 259-270.

Estes JA. 1989. Adaptions for aquatic living by carnivores. In: Gittleman JL, ed. Carnivore biology, ecology and evolution. London: Chapman and Hall, pp. 242-282.

Estes J, Riedman ML, Staedler MM, Tinker MT, Lyon BE. 2003. Individual variation in prey selection by sea otters: patterns, causes and implications. J Anim Ecol 72: 144-155.

Grant KR, Harrington LA. 2015. Fish selection by riverine Eurasian otters in lowland England. Mammal Res 60: 217-231.

Hájková P, Roche K, Kocian L. 2003. On the use of diagnostic bones of brown trout, Salmo trutta m. fario, grayling, Thymallus thymallus and Carpathian sculpin, Cottus poecilopus in Eurasian otter, Lutra lutra diet analysis. Folia Zool 52: 389-398.

Haunschmid R, Schotzko N, Petz-Glechner R, Honsig-Erlenburg W, Schmutz S, Spindler T, Unfer G, Bammer WV, Hundritsch L, Prinz H, Sasano B. 2010. Leitfaden zur Erhebung der biologischen Qualitätselemente Teil A1-Fische. Vienna: Bundesministerium für Landund Forstwirtschaft, Umwelt und Wasserwirtschaft, Sektion VII.

Heggberget TM, Moseid K-E. 1994. Prey selection in coastal Eurasian otters Lutra Iutra. Ecography 17: 331-338.

Illies J. 1961. Versuch einer biozönotischen Gliederung der Fließgewässer. Int Revue ges Hydrobiol 46: 205-213.

Jacobsen L, Hensen HM. 1996. Analysis of otter (Lutra lutra) spraints: Part 1: comparison of methods to estimate prey proportion; part 2: estimation of size of prey fish. $J$ Zool (Lond) 238: 167-180.

Klare U, Kamler JF, MacDonald DW. 2011. A comparison and critique of different scat-analysis methods for determining carnivore diet. Mamm Rev 41: 294-312.

Klenke RA, Ring I, Kranz A, Jepsen N, Rauschmayer F, Henle K. 2013. Human-wildlife conflicts in Europe. Fisheries and fish-eating vertebrates as a model case. Berlin: Springer, $347 \mathrm{p}$.

Kloskowski J. 2000. Selective predation by otters Lutra lutra on common carp Cyprinus carpio at farmed fisheries. Mammalia 64: 287-294.

Kloskowski J, Rechulicz J, Jarzynowa B. 2013. Resource availability and use by Eurasian otters Lutra lutra in a heavily modified rivercanal system. Wildlife Biol 19: 439-451.

Knollseisen M. 1996. Fischbestimmungsatlas als Grundlage für nahrungsökologische Untersuchungen, BOKU-Berichte zur Wildtierforschung und Wildbewirtschaftung 12. Wien: Universität für Bodenkultur Wien, $93 \mathrm{p}$.

Kortan D, Adámek Z, Vrána P. 2010. Otter, Lutra lutra, feeding pattern in the Kamenice River (Czech Republic) with newly established Atlantic salmon, Salmo salar, population. Folia Zool 59: 223-230.

Kranz A. 2000. Otters (Lutra lutra) increasing in Central Europe: from the threat of extinction to locally perceived overpopulation? Mammalia 64: 357-368.

Krawczyk AJ, Bogdziewicz M, Majkowska K, Glazaczow A. 2016. Diet composition of the Eurasian otter Lutra lutra in different freshwater habitats of temperate Europe: a review and metaanalysis. Mamm Rev 46: 106-113.
Kruuk H. 2006. Otters: ecology, behaviour and conservation. Oxford: Oxford University Press, $280 \mathrm{p}$.

Kruuk H, Carss D, Conroy J, Durbin L. 1993. Otter (Lutra lutra L.) numbers and fish productivity in rivers in north-east Scotland. Symp Zool Soc Lond 65: 171-191.

Lanszki J, Körmendi S, Hancz C, Martin TG. 2001. Examination of some factors affecting selection of fish prey by otters (Lutra lutra) living by eutrophic fish ponds. J Zool 255: 97-103.

Lanszki J, Lehoczky I, Kotze A, Somers MJ. 2016. Diet of otters (Lutra lutra) in various habitat types in the Pannonian biogeographical region compared to other regions of Europe. Peer J 4: e2266.

Levins R. 1968. Evolution in changing environments. Princeton: Princeton University Press, $132 \mathrm{p}$.

Lewin W-C., Arlinghaus R, Mehner T. 2006. Documented and potential biological impacts of recreational fishing: Insights for management and conservation. Rev Fish Sci 14: 305-367.

Lyach R, Cech M. 2017. Do otters target the same fish species and sizes as anglers? A case study from a lowland trout stream (Czech Republic). Aquat Living Resour 30: 11.

MacArthur RH, Pianka ER. 1966. On optimal use of a patchy environment. Am Nat 100: 603-609.

Magnhagen C. 1991. Predation risk as a cost of reproduction. Trends Ecol Evol 6: 183-186.

Manly BFJ, McDonald LL, Thomas DL, McDonald TL, Erickson WP. 2002. Resource selection by animals: statistical design and analysis for field studies. 2nd ed. London: Kluwer Academic Publishers, $222 \mathrm{p}$.

Mason CF, MacDonald SM. 1986. Otters: ecology and conservation. Cambridge: Cambridge University Press, 248 p.

Michalik M, McGill RAR, van Noordwijk HJ, Masello JF, Furness RW, Eggers T, Quillfeldt P. 2013. Stable isotopes reveal variable foraging behaviour in a colony of the Imperial Shag Phalacrocorax atriceps: differences between ages, sexes and years. J Ornithol 154: 239-249.

Nelson K, Kruuk H. 1997. The prey of otters: calorific content of eels (Anguilla anguilla) and other fish, frogs (Rana temporaria) and toads (Bufo bufo). IUCN Otter Specialist Group Bull 14: 75-80.

Oksanen J, Blanchet FG, Friendly M, Kindt R, Legendre P, McGlinn D, Minchin PR, ÓHara RB, Simpson GL, Solymos P, Stevens MHH, Szoecs E, Wagner H. 2018. Vegan: community ecology package. $R$ package version 2.4-4. https://cran.r-project.org/ package $=$ vegan.

Pagacz S, Witczuk J. 2010. Intensive exploitation of amphibians by Eurasian Otter (Lutra lutra) in the Wolosaty Stream, Southeastern Poland. Ann Zool Fennici 47: 403-410.

Pianka ER. 1973. The structure of lizard communities. Annu Rev Ecol Syst 4: 53-74.

Pinter K, Lautsch E, Unfer G, Hayes DS. 2018. Snorkeling-based fish stock assessment by anglers - a valuable method for managing recreational fisheries. $N$ Am J Fish Manage https://doi.org/10.1002/ nafm.10246.

Pletterbauer F, Melcher AH, Ferreira T, Schmutz S. 2015. Impact of climate change on the structure of fish assemblages in European rivers. Hydrobiologia 744: 235-254.

Pyke GH, Pulliam HR, Charnov E. 1977. Optimal foraging: a selective review of theory and tests. $Q$ Rev Biol 52: 137-154.

Rauschmayer F, Wittmer H, Berghöfer A. 2008. Institutional challenges for resolving conflicts between fisheries and endangered species conservation. Mar Policy 32: 178-188.

R Core Team. 2017. R: a language and environment for statistical computing. Vienna: R Foundation for Statistical Computing, Austria. https://www.R-project.org/. 
Redpath SM, Young J, Evely A, Adams WM, Sutherland WJ, Whitehouse A, Amar A, Lambert RA, Linnell JDC, Watt A, Gutiérrez RJ. 2013. Understanding and managing conservation conflicts. Trends Ecol Evol 28: 100-109.

Reid N, Thompson D, Hayden B, Marnell F, Montgomery WI. 2013. Review and meta-analysis of diet suggests the Eurasian otter (Lutra lutra) is likely to be a poor bioindicator. Ecol Indic 26: 5-13.

Remonti L, Prigioni C, Balestrieri A, Sgrosso S, Priore G. 2008. Trophic flexibility of the otter (Lutra lutra) in southern Italy. Mamm Biol 73: 293-302.

Remonti L, Balestrieri A, Prigioni C. 2009. Altitudinal gradient of Eurasian otter (Lutra lutra) food niche in Mediterranean habitats. Can J Zool 87: 285-291.

Remonti L, Prigioni C, Balestrieri A, Sgrosso S, Priore G. 2010. Eurasian otter (Lutra lutra) prey selection in response to a variation of fish abundance. Ital J Zool 77: 331-338.

Ripple WJ, Estes JA, Beschta RL, et al. 2014. Status and ecological effects of the world's largest carnivores. Science 343: 1241484.

Roos A, Loy A, de Silva P, Hajkova P, Zemanová B. 2015. Lutra lutra. The IUCN Red list of threatended species 2015: e. T12419A21935287. http://dx.doi.org/10.2305/IUCN.UK 2015-2. RLTS.T12419 A21935287. en. Downloaded on 26 June 2018.

Rosenblatt AE, Nifong JC, Heithaus MR, Mazzotti FJ, Cherkiss MS, Jeffery BM, Elsey RM, Decker RA, Silliman BR, Guillette LJ, Lowers RH, Larson JC. 2015. Factors affecting individual foraging specialization and temporal diet stability across the range of a large "generalist" apex predator. Oecologica 178: 5-16.

Ruiz-Olmo J, Jiménez J. 2009. Diet diversity and breeding of top predators are determined by habitat stability and structure: a case study with the Eurasian otter (Lutra lutra L.). Eur J Wildl Res 55: 133-144.

Ruiz-Olmo J, López-Martín JM, Palazón S. 2001. The influence of fish abundance on the otter (Lutra lutra) populations in Iberian Mediterranean habitats. $J$ Zool 254: 325-336.

Ruiz-Olmo J, Batet A, Manas F, Martínez-Vidal R. 2011. Factors affecting otter (Lutra lutra) abundance and breeding success in freshwater habitats of the north-eastern Iberian Peninsula. Eur $J$ Wildl Res 57: 827-842.

Sales-Luís T, Pedroso NM, Santos-Reis M. 2007. Prey availability and diet of the Eurasian otter (Lutra lutra) on a large reservoir and associated tributaries. Can J Zool 85: 1125-1135.

Schinegger R, Trautwein C, Melcher A, Schmutz S. 2012. Multiple human pressures and their spatial patterns in Europen running waters. Water Environ J 26: 261-273.

Schinegger R, Palt M, Segurado P, Schmutz S. 2016. Untangling the effects of multiple human stressors and their impacts on fish assemblages in European running waters. Sci Total Environ 573: 1079-1088.

Sittenthaler M, Bayerl H, Unfer G, Kuehn R, Parz-Gollner R. 2015. Impact of fish stocking on Eurasian otter (Lutra lutra) densities: a case study on two salmonid streams. Mamm Biol 80: 106-113.

Smiroldo G, Balestrieri A, Remonti L, Prigioni C. 2009. Seasonal and habitat-related variation of otter Lutra lutra diet in a Mediterranean river catchment (Italy). Folia Zool 58: 87-97.

Smith EAE, Newsome SD, Estes JA, Tinker MT. 2015. The cost of reproduction: differential resource specialization in female and male California sea otters. Oecologia 178: 17-29.
Stendera S, Adrian R, Bonada N, Cañedo-Arguelles M, Hugueny B, Januschke K, Pletterbauer F, Hering D. 2012. Drivers and stressors of freshwater biodiversity patterns across different ecosystems and scales: a review. Hydrobiologia 696: 1-28.

Stephens DW, Krebs JR. 1986. Foraging theory. Princeton: Princeton University Press, $262 \mathrm{p}$.

Stewart DC, Middlemas SJ, Gardiner WR, Mackay S, Armstrong JD. 2005. Diet and prey selection of cormorants (Phalacrocorax carbo) at Loch Leven, a major stocked trout fishery. J Zool 267: 191-201.

Stöger E. 2016. The impact of the recent resettlement of European otter (Lutra lutra) on salmonid stocks of Lower Austrian streams An analysis of environmental conditions and fish stock development (in German with english abstract). Vienna: Master Thesis, BOKU University of Natural Resources and Life Sciences, 122 p.

Svanbäck R, Bolnick DI. 2005. Intraspecific competition affects the strength of individual specialization: an optimal diet theory method. Evol Ecol Res 7: 993-1012.

Taastrom H, Jacobsen L. 1999. The diet of otters (Lutra lutra L.) in Danish freshwater habitats: comparisons of prey fish populations. $J$ Zool 248: 1-13.

Tudorache C, Viaene P, Blust R, Vereecken H, De Boeck G. 2008. A comparison of swimming capacity and energy use in seven European freshwater fish species. Ecol Freshw Fish 17: 284-291.

Unfer G, Pinter K. 2018. Fisheries management of stream-resident brown trout populations - possibilities and restrictions. In: LobónCerviá J, Sanz N, eds. Brown Trout: Biology, Ecology and Management. Hoboken, New Jersey: John Wiley \& Sons, pp. 649 665.

Unfer G, Hauer C, Pinter K. 2011. Spawning redds of brown trout in geologically different streams. In: American Fisheries Society, ed. New frontiers in fisheries management and ecology: leading the way in a changing world. Seattle, USA: American Fisheries Society 141st Annual Meeting.

Van den Brink PJ, Ter Braak CJF. 1999. Principal response curves: analysis of time-dependent multivariate responses of biological community to stress. Environ Toxicol Chem 18: 138-148.

Van den Brink PJ, Van den Brink NW, Ter Braak CJF. 2003. Multivariate analysis of ecotoxicological data using ordination: demonstrations of utility on the basis of various examples. Austral $J$ Ecotoxicol 9: 141-156.

Van den Brink PJ, Den Besten PJ, Bij De Vaate A, Ter Braak CJF. 2009. Principal response curves technique for the analysis of multivariate biomonitoring time series. Environ Monit Assess 152: 271-281.

Vucetich JA, Peterson RO, Schaefer CL. 2002. The effect of prey and predator densities on wolf predation. Ecology 83: 3003-3013.

Watt J. 1993. Ontogeny of hunting behavour of otters (Lutra lutra L.) in a marine environment. Symp Zool Soc Lond 65: 87-104.

Webb JB. 1976. Otter spraint analysis. The Mammal Society, Reading, $12 \mathrm{p}$.

Weber ED, Fausch KD. 2003. Interactions between hatchery and wild salmonids in streams: differences in biology and evidence for competition. Can J Fish Aquat Sci 60: 1018-1036.

Wise MH. 1980. The use of fish vertebrae in scats for estimating prey size of otters and mink. J Zool (Lond) 195: 181-213.

Cite this article as: Sittenthaler M, Koskoff L, Pinter K, Nopp-Mayr U, Parz-Gollner R, Hackländer K. 2019. Fish size selection and diet composition of Eurasian otters (Lutra lutra) in salmonid streams: Picky gourmets rather than opportunists? Knowl. Manag. Aquat. Ecosyst., 420,29 . 